\title{
Els drets sobre la pesca a l'Alt Maresme (terme de Montpalau). Delme, castellatge i peix senyoriu (segles XIII-XVI)
}

Fishing rights in the Alt Maresme (barony of Montpalau). Tithes, castellatge and royal fish (13th-16th centuries)

Los derechos sobre la pesca en el Alt Maresme (término de Montpalau). Diezmo, castellatge y pez señorial (siglos XII-XVI)

Antoni Ginot Julià ${ }^{1}$

\section{Resum}

En la història de la renda senyorial, els drets sobre la pesca tenen un paper importantíssim en les senyories que comptaven amb activitat pesquera. Aquí ens centrarem en els drets que es documenten al llarg de quatre segles (xIII-Xvi) a la baronia de Montpalau (Maresme), integrada al vescomtat de Cabrera. L'objectiu de l'estudi present és copsar com van evolucionar, entendre la vinculació que mantingueren amb la senyoria jurisdiccional i documentar drets poc estudiats: el castellatge del peix, per exemple.

Paraules clau: Pesca, renda, feudalisme, delmes, castlania, Montpalau.

\begin{abstract}
In the history of seignorial rent, fishing rights played an important role in those seigneuries which encompassed fishing activities. Here we will focus on those documented over four centuries (13th-16th) in the barony of Montpalau (Alt Maresme), integrated in the viscounty of Cabrera. The objective of this study is to understand the evolution of these rights, their link with jurisdictional seigneury, and document less studied rights, such as castellatge.
\end{abstract}

Keywords: Fishing, rent, feudalism, tithes, Montpalau.

1. ORCID: 0000-0002-5383-9833. Institut de Recerca Històrica, Universitat de Girona. Correu electrònic: tginot@gmail. com. Aquest treball està vinculat al projecte de recerca «iCambio social sin grupos sociales? El seguimiento de trayectorias colectivas en el pasado desde una perspectiva relacional (siglos XIV-XIX) RECSNETS I», del Ministeri de Ciència, Innovació i Universitats (PGC2018-096350-B-100).

Rebut: IV/2021. Avaluat: V/2021. Versió definitiva: VI/2021. 


\section{Resumen}

En la historia de la renda señorial, los derechos sobre la pesca tienen un papel importantísimo en los señoríos que contaban con actividad pesquera. Aquí nos centraremos en los derechos que se documentan a lo largo de cuatro siglos (xIII-xvi) en la baronía de Montpalau (Maresme), integrada en el vizcondado de Cabrera. El objetivo del presente estudio es entender como evolucionaron, entender la vinculación que mantuvieron con el señorío jurisdiccional y documentar los derechos poco estudiados: el castellatge del pescado, por ejemplo.

Palabras clave: Pesca, renda, feudalismo, diezmos, castellanía, Montpalau.

\section{Introducció}

Quan sentim a parlar del camp en l'edat mitjana no se'ns fa difícil imaginar una pagesia esllomant-se a les terres de conreu per obtenir uns fruits que haurà de lliurar en part al seu senyor per tal de satisfer les imposicions corresponents. Ara bé, aquesta imatge tòpica amb tots els detalls i matisos que cal tenir en compte també hauria de ser igualment aplicada als que es dedicaven a les feines de la mar. En concret, els pescadors havien de satisfer regularment uns gravàmens de diversa índole a un o més senyors.

Aquest estudi pretén ser una aproximació als drets cobrats sobre la pesca en un punt concret del nostre territori. ${ }^{2}$ Ens centrarem especialment en els tres drets que s'han documentat al terme de Montpalau, al Maresme, i que apareixen regularment en la documentació de les senyories del litoral: el delme del peix, que suposava el pagament d'una part proporcional del que es pescava; el castellatge del peix, que era un pagament rebut pels castlans com a remuneració per les seves funcions, i el peix senyoriu, un dret que gravava unes espècies de peix de dimensions generalment grans i es cobrava amb una part dels exemplars pescats. Amb tot, doncs, aquestes pàgines se centraran en un estudi de cas d'un tema de més complexitat i extensió, amb la voluntat que els resultats aquí exposats es puguin extrapolar a altres zones de Catalunya i de la Mediterrània. L'objectiu de tot plegat és donar un cop d'ull a les característiques i les complexitats d'aquests drets en un punt de la Catalunya Vella.

L'espai nord-oriental del Maresme, el terme de Montpalau, ha estat triat, com es podrà veure al llarg de l'article, perquè les exaccions sobre la pesca documentades tenen, podríem dir-ne, un gran dinamisme. El canvi de mans dels drets està a l'ordre del dia i les donacions d'aquests mateixos drets se succeeixen l'una rere l'altra, configurant un cas de molt interès per a l'estudi de les exaccions sobre el peix. Dels tres drets que s'han pogut documentar a Montpalau, en desgranarem les característiques i la seva evolució cronològica.

2. Al llarg de l'article evitarem parlar de fiscalitat en tant que entenem que el concepte només és aplicable a exigències derivades del poder públic. 
Així, esperem poder dibuixar una petita part del gran esquema dels drets sobre el peix als Països Catalans i a la Mediterrània. El cas de la pesca a Montpalau, no estudiat en profunditat fins al moment, serveix, doncs, de testimoni de l'evolució general d'alguns d'aquests drets. A més, i per sobre de tot, conté alguns dels casos més excepcionals relatius a les exaccions pesqueres, almenys del litoral de la Catalunya Vella. ${ }^{3}$

\section{Context}

\section{L'espai}

A Catalunya, més enllà de la prou extensa divisió en comarques, hom pot endinsar-se en tot un món de comarques històriques, subcomarques i comarques naturals que fan ballar totes les línies del mapa. Una de les regions on més passa això és a la meitat superior del Maresme, avui dia anomenat Alt Maresme. Aquesta regió també rep el nom de Marina de la Selva, a causa de la seva pertinença a l'ardiaconat homònim del bisbat de Girona i, per tant, de la comarca històrica de la Selva. ${ }^{4}$ Aquest conjunt de poblacions, agrupades sota el terme castral de Montpalau, formava part de l'antic vescomtat de Cabrera, i pràcticament en configurava la meitat de la línia de costa.

El terme de Montpalau, anomenat igualment baronia de Montpalau, rep el nom del castell que hi ha a l'actual municipi de Pineda de Mar. Aquest castell, a l'inici alou del comte de Barcelona, va passar a ser de total domini dels Cabrera el 1277, que ja hi tenien drets des de 1113.5 Sota la jurisdicció d'aquest castell s'agrupaven les parròquies de Santa Maria i Sant Pere de Pineda, Sant Miquel de Vallmanya, Santa Eulàlia d'Hortsavinyà, Sant Cebrià i Sant Iscle de Vallalta i Sant Martí d'Arenys. Totes elles parròquies de les quals al segle xvi s'escindiren poblacions costaneres que ja feia un parell de segles que s'anaven configurant: Calella (a Santa Maria de Pineda), Sant Pol (a Sant Cebrià de Vallalta), Canet (a Sant Iscle de Vallalta) i Arenys de Mar (a Sant Martí d'Arenys). En tots aquests pobles es documenten pescadors en més o menys nombre, especialment a partir de mitjan segle xv i principis del

3. El tema de la renda feudal sobre les activitats halièutiques ha estat tractat per alguns autors de l'àmbit mediterrani. A França i Itàlia ha esta prou treballat i s'han fet diverses aportacions: CoL.ET, Serge (1987). «Le Baron et le Poisson: Féodalité et Droit de la Mer en Europe occidentale». Dins Droit et Cultures, n. 13, p. 25-49; Montanari (1999); MarTelLucci, Maura (2001). «La pesca in mare». Dins Balestracci, Duccio; Pasin, Paolo. Pesca e pescatori: dal tardo medioevo allà prima etá moderna. Milà: Leonardo Arte, p. 27-51. Especialment destacables, en l'àmbit italià, són els escrits de Zug Tucci (1983) i Vendittelli (1992). A Catalunya, encara s'ha de fer més recerca en profunditat sobre aquest tema, sobretot a l'edat mitjana. Els estudis que hi han dedicat algun apartat de moment se centren sobretot en l'Empordà de l'edat moderna i baixmedieval: Garrido (2011); Pujol (2014), (2018). Manquen, doncs, articles i estudis monogràfics centrats únicament en l'aspecte dels drets de pesca.

4. El tema de la concepció selvatana és complex i ha generat diversa, però al meu parer no suficient, bibliografia. Si en voleu més informació vegeu SALAMAÑa, Isabel (1990). La Selva: Estructura sòcio-econòmica d'una comarca beterogènia. Barcelona: Caixa de Catalunya; Burgueño, Jesús (2002). «Identitat i administració a la Selva: una dualitat irresoluble?», Quaderns de la Selva núm. 14, p. 33-58; Mallorquí, Elvis (2011). «L'Edat Mitjana». Dins: Figueras, Narcís; Luinàs, Joan. Història de la Selva. Girona: Diputació de Girona, p. 215-348.

5. Martínez (2009): 26-27; Pons Guri (2003): 523. 
Xvi. En concret, entre tots ells Sant Pol de Mar s'erigí, amb el temps, com el poble pesquer per excellència. ${ }^{6}$ Sense anar més lluny, ja a principis del xvı és la localitat de l'Alt Maresme amb més gent de mar. ${ }^{7}$

\section{Mapa 1 \\ El terme del Castell de Montpalau coincideix amb bona part de l'actual comarca del Maresme}
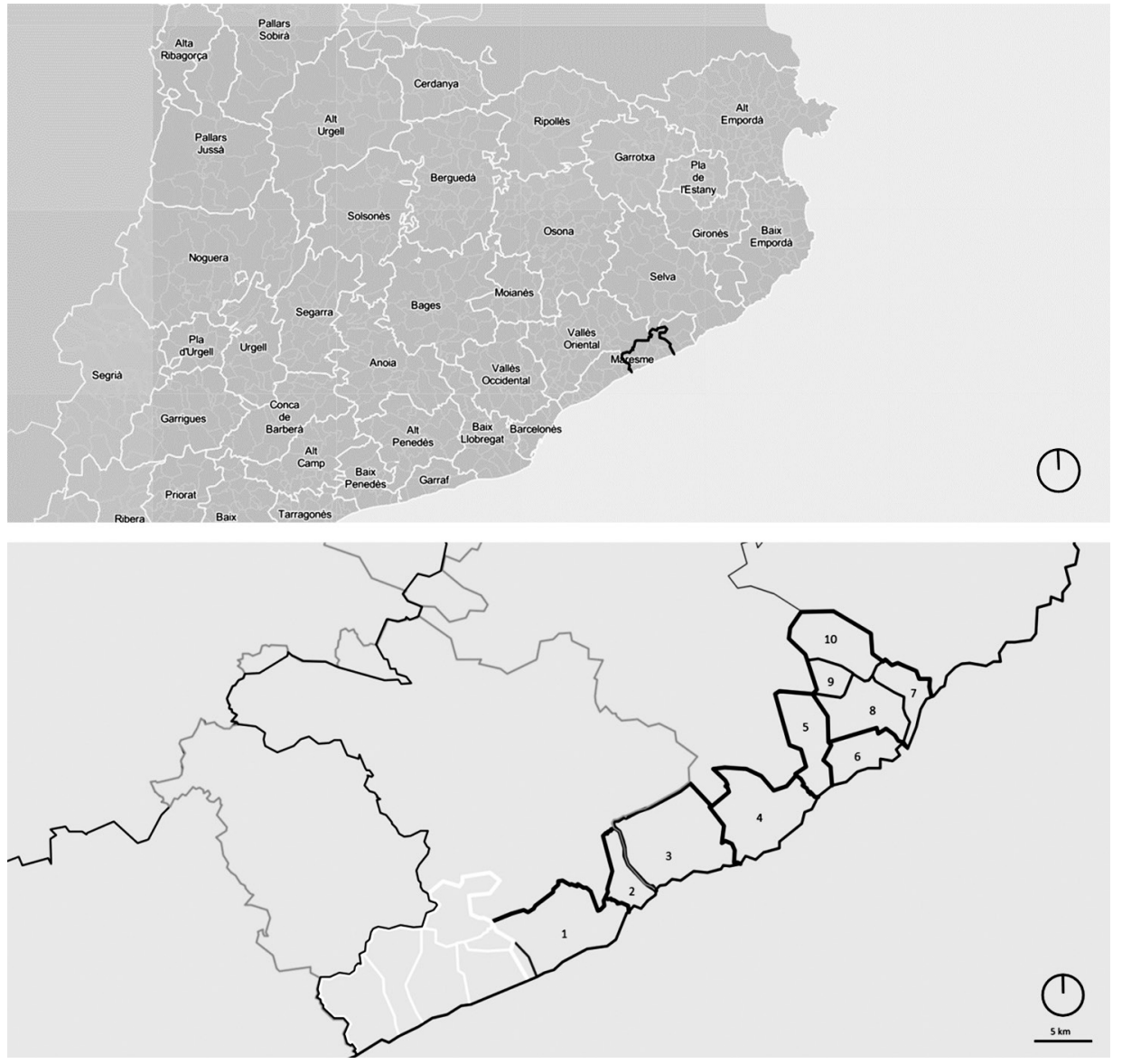

A baix (en blanc) es pot veure en relació amb la resta de termes i parròquies de l'ardiaconat de la Selva (1: Palafolls, 2: Blanes, 3: Lloret, 4: Tossa, 5: Solius, 6: Sant Feliu de Guíxols, 7: Fenals d'Aro, 8: Castell d'Aro, 9: Belllloc i 10: Romanyà de la Selva (Instamaps. Antoni Ginot, 2021).

6. Carbonell (2010): 230-231.

7. Soldevila (2017): 77. 


\section{Els senyors}

Com hem dit, la baronia de Montpalau estigué senyorejada pels Cabrera, que l'uniren al seu vast patrimoni al sud de les comarques gironines. Els Cabrera obtingueren el castell de Montpalau el 27 de maig de 1113, tot i que, com hem dit, no n'eren els senyors aloers. A més, havien de compartir competències amb els senyors del Montseny, que encara hi conservaven alguns drets, entre els quals el delme del peix. ${ }^{8}$ Els Umbert de Basella, senyors del Montseny, senyorejaven els castells de Ses Agudes, Miravalls i Montclús del qual prengueren el nom. ${ }^{9}$ Ara bé, tal com indica la concòrdia de 1113, els Umbert no eren sinó subfeudataris dels vescomtes de Girona (després anomenats de Cabrera). ${ }^{10}$

Els Cabrera i els Montseny-Montclús anaren estrenyent llaços amb diferents matrimonis tot i que els segons mantingueren l'estatus al costat d'uns vescomtes cada cop més forts i amb un patrimoni que creixia dia rere dia. Finalment, Riembau de Montclús, fill de Gueraua de Cabrera i Guillem de Montclús, senyor de Montclús i de Montpalau, en tant que subfeudatari dels Cabrera, transmeté tots els drets sobre els seus dominis al seu oncle Guerau VI de Cabrera el 22 de maig de 1277. ${ }^{11}$ Només calia que el rei els donés el domini aloer del castell als Cabrera per esdevenir-ne senyors indiscutibles. Tal cosa s'assolí gràcies a la destacada actuació de Bernat II de Cabrera en la guerra sarda, i el 3 de setembre de 1324 es concedia la potestat del castell, tot i que no es confirmà fins al 26 d'octubre de $1328 .{ }^{12}$ Des d'aquell moment el castell, i el terme, van restar sempre en mans dels Cabrera i els seus successors.

És destacable el fet que, des del segle xiv, el castell de Montpalau només era un edifici abandonat. Tal cosa, però, no impedí en cap moment el manteniment de la jurisdicció castral. ${ }^{13}$ De totes maneres, aquesta destrucció de l'edifici sí que afectà la pervivència de la figura del castlà, un càrrec que també tingué una forta vinculació amb els drets de pesca. En general, però, són poques les referències a castlans designats com a tals al vescomtat, i tots en dates tardanes, quan les castlanies ja no són sinó títols posseïts per famílies en busca de beneficis a través de les rendes. ${ }^{14}$ Tal cosa devia afavorir el declivi del castell de Montpalau i la seva família de castlans homònima, de cap a caiguda des de la mort de Ponç de Montpalau el $1230 .{ }^{15}$ Finalment, els darrers anys del segle xiII ja no queden castlans a Mont-

8. Martínez (2009): 26-27; ACA, Ordes Religiosos i Militars (d'ara endavant ORM), Monacals-Hisenda, vol. 2103, ff. 4v-5r (1224 gener 4).

9. També havien arribat a tenir els castells de Palafolls i Lloret; Martínez (2009): 26.

10. Pons Guri (2003): 523 .

11. Acte mogut possiblement pels conflictes amb l'orde de l'Hospital, senyors de Sant Celoni; Pons Guri (2003): 524-525; Martínez (2009): 26.

12. Pons Guri (2003): 526 i 531-532; Martínez (2015): 177.

13. Pons Guri (2003): 528.

14. Martínez (2015): 566.

15. Martínez (2015): 441-442 i 566-568. Sembla que la castlania tenia una batllia associada, anomenada de la castlania, amb competències en un sector del terme. A banda, hi hauria el batlle jurisdiccional, el de Sant Pere de Pineda i el de Sant Martí d'Arenys. 
palau, i els seus drets van ser liquidats a mans d'Arnau de Pontons, darrer castlà. ${ }^{16} \mathrm{El} 20$ de maig de 1294, Arnau ven la castlania a Ramon de Cabrera, i així posà fi a aquest càrrec a la baronia. ${ }^{17}$ Sembla que entre aquests drets de la castlania també n'hi devia haver alguns sobre la pesca, documentats almenys entre 1224 i $1339 .{ }^{18}$

Encara que els Cabrera i els Montclús fossin senyors del terme castral, dins d'aquest hi havia diverses cases aloeres, com la de Canet o la de Menola. A més, s'hi havia erigit el monestir de Sant Pau del Maresme, ${ }^{19}$ que, en el tema que ens ocupa, tingué un destacat protagonisme poc treballat fins al moment.

Sant Pau del Maresme s'aixeca sobre unes restes possiblement tardoantigues o dels primers segles medievals, tot i que el cenobi no es documenta com a tal fins al segle.$^{20} \mathrm{~A}$ l'inici tingué lligams amb Sant Feliu de Guíxols, per bé que Sant Pau anà decaient i, a mitjan segle xi estava en un estat ruïnós. ${ }^{21}$ Possiblement amb l'objectiu de palliar aquesta situació, el 2 de gener de 1069 Ramon Berenguer i Almodis el donaren a l'abat de Sant Honorat de Lerins. Així doncs, Sant Pau passà a ser un priorat d'aquest monestir. ${ }^{22}$ De totes maneres, els monjos provençals no aconseguiren millorar un problema d'inestabilitat que esdevingué endèmic en el cenobi, i aquest s'acabà venent al sagristà de Girona Guillem de Montgrí. És en aquest moment que el monestir de Sant Pau adquireix la condició de castell, o almenys es pretén que així sigui. ${ }^{23}$

La venda s'efectuà el 5 de juny de 1265, i en ella es denominà castrum Sancti Pauli de Maritima, el qual es venia cum terminis et iurisdictionibus, vicibus et dominiiis. ${ }^{24}$ La dotació d'aquest estatus topa amb el fet que ja es trobava dins un terme castral en si mateix. Així doncs, en aquest punt, Sant Pau no deixava de tenir la mateixa condició que qualsevol casa aloera de la zona. ${ }^{25}$

Si bé Sant Pau no va tenir mai un terme pròpiament dit, sí que va comptar, des del segle xiII, amb un espai ben delimitat sobre el qual se li van donar alguns drets. Es tracta dels drets sobre el boscar i la pesca, que tractarem més endavant. El terme que se li atorgà, coincident amb l'actual municipi de Sant Pol de Mar, fou anomenat terminus franquesie. ${ }^{26}$ No fou gaire més tard, el 1270, que Guillem de Montgrí vengué el monestir ara anomenat

16. Pons Guri (2003): 527. Entre les vendes hi ha el dret de farga a Arenys: ACA, ORM, Pergamins de Santa Maria de Montalegre, núm. 527 (1272 maig 3).

17. ADM, Cabrera i Bas, lligall 10, n. 65 (AHH, Cabrera i Bas, 3138).

18. ACA, ORM, Monacals-Hisenda, vol. 2103.

19. Per afavorir la comprensió i evitar confusions, ens referirem al monestir com a Sant Pau del Maresme, i al nucli habitat al seu voltant (germen de l'actual municipi de Sant Pol de Mar) com a Sant Pol. Convé recordar que, malgrat l'hagiotopònim, no ha existit mai una parròquia de Sant Pol. En l'època que ens ocupa es trobava dins la parròquia de Sant Cebrià de Vallalta.

20. Pons Guri (1989): 365; Graupera (2016): 15.

21. Genera, et al.; Graupera (2016): 17.

22. Pons Guri (1989): 366.

23. Genera, et al.

24. ACA, ORM, Monacals-Hisenda, vol. 2103, ff. 6r-8r (1265 juny 5).

25. Pons Guri (1989): 200.

26. ACA, ORM, Monacals-Hisenda, vol. 2103, ff. 4v-5v (1224 gener 4 i 1224 gener 5). 
castell a l'orde de la Cartoixa, establerts ja a Catalunya al monestir d'Scala Dei. ${ }^{27}$ Els cartoixans tingueren el monestir fins que, altre cop, decidiren abandonar-lo, possiblement a causa de la inestabilitat i els constants conflictes amb els Cabrera. Així doncs, el 1434 l'edifici de Sant Pau, anomenat altre cop castell, passà a mans dels Cabrera, i els monjos es traslladaren a la recentment fundada cartoixa de Montalegre. ${ }^{28}$

A banda dels senyors del terme, els castlans i el monestir de Sant Pau, cal afegir a aquest relat un altre protagonista: l'hospital de pobres d'Hostalric. La primera notícia d'aquest hospital, fundació dels vescomtes de Cabrera, és de 1330, any que se li donen indulgències. ${ }^{29}$ La fundació de l'hospital fou iniciativa de Bernat II i la seva mare Elionor d'Aguilar, l'única fundació ex nibilo dels Cabrera als segles XIII i xIv. La llicència episcopal per a la seva construcció es donà el 1340, i se li assignà el delme del roldor, les olives i el peix del terme de Montpalau, per tal de mantenir-lo. ${ }^{30} \mathrm{~A}$ banda de cobrar aquests delmes, l'hospital d'Hostalric posseïa drets sobre masos i terres en diversos llocs de la Marina de la Selva. ${ }^{31}$

\section{L'activitat pesquera}

L'activitat pesquera fou present al terme de Montpalau molt probablement ja des de temps altmedievals, tot i que la primera referència que en tenim és a través de la ja esmentada donació dels drets a Sant Pol el 1224. De fet, a poblacions com Tossa o Sant Feliu ja es documenta en dates tan antigues com el 966 i el 1144 respectivament. ${ }^{32}$ En aquesta zona, però, la pesca devia anar lligada de manera estreta a tot el procés de poblament de l'espai més immediatament litoral. La baronia de Montpalau, i l'Alt Maresme en general, eren, en plena edat mitjana, una zona muntanyosa amb predomini de l'hàbitat dispers. No fou fins als segles xIv i xv que en part per iniciativa senyorial es poblaren i consolidaren viles costaneres com Canet, Calella o la Vilanova de Palafolls (Malgrat de Mar). ${ }^{33}$

De tota manera, encara és un tema que cal tractar amb més profunditat. El buidatge del fons notarial de Montpalau i dels pergamins de diverses procedències donen molt poques dades sobre pescadors a la primera meitat del xv, i només s'hi documenten sis pes-

27. Pons Guri (1989): 200.

28. Pons Guri (1989): 200; Pons Guri (1931): 426-429.

29. ADG, Lletres, vol. U-4, f. 106r (1330 juliol 06).

30. Martínez (2015): 389; ADG, Mitra, 111 12, c. 12, n. 14 (1340 desembre 3) (còpia de 1554). L'oli i el roldor són dos productes documentats al terme de Montpalau. Per exemple, el 1331 Pere Verneda, de Torrentbó, parròquia de Sant Martí d'Arenys, ven un censal d'un quarter d'oli de pensió al prior de Sant Pau; ACA, ORM, Pergamins de Santa Maria de Montalegre, 1235 (1331 agost 23). D’altra banda, el roldor, arbust utilitzat per adobar les pells, és documentat el 1342 en un establiment d'un tros de terra cum roudorario; ACA, ORM, Pergamins de Santa Maria de Montalegre, 1377 (1342 maig 12). De manera més interessant es documenta aquest mateix producte el 1336, quan Berenguer Gilabert, subsaig del terme de Montpalau, reconeix haver rebut de Guillem de Mas, de Buadelles, 50 sous de 120 quarteres de roldor quas michi debere recognouistis; ACA, ORM, Pergamins de Santa Maria de Montalegre, 1278 (1336 febrer 9).

31. AHFF, pergamins, n. 759 (1396 gener 27); n. 765 (1397 juny 8); n. 766 (1397 setembre 26); n. 892 (1419 maig 12).

32. Esteva, Pallí (1995): 86; Pons Guri (1989): 9-15.

33. Soldevila (2018): 17-19. 
cadors: cinc de Canet i un de Sant Pol. ${ }^{34}$ D'altra banda, en diferents capbreus de principis del xvi es pot obtenir una imatge més àmplia però en cap cas definitòria de la presència del collectiu al terme, juntament amb el dels mariners: 27 mariners i pescadors en total. ${ }^{35}$

Els pescadors medievals tenien un divers ventall d'arts de pesca, des dels més simples com el palangre i el volantí fins a la tonaira o l'omnipresent xàvega. ${ }^{36}$ Aquest darrer va ser possiblement l'art més utilitzat dels segles medievals. Es tractava d'una xarxa amb forma de sac que s'estirava des de la platja després d'haver estat calada per una barca que deixava un extrem del cap a terra i descrivia un semicercle en la mar per retornar-ne l'altra a la costa, des d'on era estirada per diverses persones o terramaners. ${ }^{37}$ També es feia servir una versió reduïda de la xàvega, el bolig. Si s'utilitzava foc per atreure les moles de peix blau durant la nit, la tècnica prenia el nom d'encesa. Tant la xàvega com el bolig i l'art, xarxa similar a vegades indistingible amb les altres dues eren comuns a les nostres costes des del segle XII. ${ }^{38}$

Si bé aquests arts eren estirats des de la platja, cosa que, en principi, afavoria el control sobre el pagament de drets senyorials, n'hi havia d'altres que es calaven directament en la mar, i això causava més maldecaps. ${ }^{39}$ D'aquests arts en destaca el palangre, que era una corda de cànem amb uns quants hams penjant, una pedra lligada en un dels caps i en l'altre una boia que permetia localitzar l'art entre l'onatge. ${ }^{40}$ La distinció entre pescadors de xàvega i de palangre estigué present al llarg de tota l'edat mitjana i els segles moderns. Així doncs, la confraria de Sant Pere i Sant Andreu de pescadors de Tarragona en distingia els dos tipus a l'hora de regir-la. ${ }^{41}$ De manera similar, a l'àrea que ens ocupa, trobem també que es distingeix entre «piscibus exavagarum» $\mathrm{i}$ «barcharum»: peixos de xàvega i de barca. ${ }^{42}$

Altres arts habituals eren les nanses: cistelles que feien de trampa per al peix i marisc, i la tonaira: art introduit a la baixa edat mitjana per pescar tonyines, entre d'altres. ${ }^{43}$

\section{Els drets sobre la pesca}

Amb l'adveniment del feudalisme, les zones litorals i la mar veieren afectat el seu estatus. Si bé en època romana el mar era considerat un bé comunal, a l'edat mitjana es produí un

34. Aquests són: Guillem Mas, originari de Blanes, habitant a Canet (ADM, Cabrera i Bas, lligall 49, n. 1 (1428)); Joan Oliu, àlies Mata, Canet (AHG, Notarials, Blanes 420, f. 12v (1458 agost 18)); Bernat Oliver, Sant Pol (AHFF, Notarials, Montpalau 1, f. 17r (1414 octubre 12)); Antoni Pla, Canet (AHG, Notarials, Blanes 400, f. 70v (1435 abril 19)); Macià Roig, Canet (ADM, Cabrera i Bas, lligall 49, n. 1 (1428)); Salvador Roig, Canet (AHMC, Pergamins, n. 499 (1447 octubre 9)).

35. Soldevila (2017): 77.

36. Per a una bona relació d'arts de pesca tradicionals vegeu Sáñez (1795). Malgrat ser molt antic segueix essent l'obra de referència per estudiar els arts de pesca tradicionals.

37. Sáñez (1795): 352-358.

38. Zucchitello (1998): 150-151

39. Pujol (2014): 41-42; Zucchitello (2011): 340

40. Riera (2009): 124-125.

41. Recasens (1997): 86.

42. ACA, ORM, Monacals-Hisenda, vol. 2103, f. 25r (1339 desembre 18).

43. Riera (2009): 125; Garrido, et. al. (2010): 32-33. 
procés d'apropiació del litoral per part dels senyors i, per tant, també de l'espai marítim immediat. ${ }^{44}$ Així doncs, els senyors començaren a gravar l'activitat pesquera amb diverses exaccions que podien afectar alguns peixos en concret o bé la pescada en general. A la baronia de Montpalau, com hem dit, se'n documenten tres drets diferents: el delme del peix, el castellatge del peix i el peix senyoriu.

\section{El delme del peix}

De totes les exaccions que afectaven la pesca, el delme del peix en fou la principal i la que es mantingué més o menys intacte, almenys fins a principis del segle xix. ${ }^{45}$

Aquest dret, que suposa l'obtenció de part del que es pesca, es documenta en diferents localitats del litoral des del segle x, per la qual cosa suposem que ja es devia cobrar amb certa anterioritat. ${ }^{46} \mathrm{Tal}$ com constata Elvis Mallorquí en el seu estudi del Llibre verd, el delme del peix devia estar estretament vinculat amb els castells termenats. Així doncs, almenys a Girona, no documentem cap relació directa d'aquest dret amb la parròquia. Mallorquí destaca que la vinculació devia ser originada per la tardana ocupació del litoral gironí als segles IX-X, quan s'aixecaren els castells. Amb l'establiment d'aquestes jurisdiccions, suposem que els comtes atorgaren els drets sobre la pesca els delmes als senyors dels castells i als monestirs que s'havien establert al llarg del litoral. ${ }^{47}$ De la mateixa manera, els monestirs que senyorejaven termes litorals també posseïen aquests drets. És a dir, els drets de pesca són drets indestriables de la senyoria jurisdiccional, la que depèn del senyor del terme. Així, el delme del peix s'ha volgut veure com un cànon que cal pagar a canvi de permetre la pesca en les aigües del senyor del lloc. ${ }^{48}$ Per tant, un senyor territorial, per exemple un cavaller d'una casa forta com la de Canet o Pineda, no tenia a priori drets sobre la pesca. Així doncs, el monestir de Sant Pau, que no posseïa la senyoria jurisdiccional del terme del voltant, no hauria hagut de ser senyor del delme del peix. Tot i així n'esdevingué una excepció. ${ }^{49}$

Al segle xiv, doncs, al litoral gironí el delme del peix era cobrat generalment pels senyors dels castells termenats i pels monestirs que posseïen la jurisdicció dels territoris cir-

44. Garrido (2011): 47-49.

45. A banda de «delme del peix» o decima piscium, també es pot trobar mencionat com a «ribatge», arribatgiis o «dret de la mar», entre d'altres; ACA, ORM, Monacals-Hisenda, vol. 2103, f. 24v; AHG, Notarials, Vall d'Aro 274, f. 81r; ACG, Pabordia de Novembre, 5.5.1, f. 4v.

46. A Tossa, en la donació de l'alou al monestir de Ripoll de 966 aquest es dona juntament amb totes les pesqueres (és a dir, el dret sobre el que es pesca: el delme). Aquests drets de pesca es confirmaren per butlla papal el 1097; Zucchitello (1998): 131. A Roses es documenten diversos drets sobre la pesca el 1117; Pujol (2014): 36. A Sant Feliu de Guíxols, el delme del peix es documenta per primer cop el 1103; Esteva, Pallí (1995): 73.

47. Mallorquí (2011): 104-106.

48. Montanari (1999): 49.

49. Els monestirs que posseïen el delme del peix al litoral de Girona eren els següents: Sant Quirze de Colera, Sant Pere de Rodes, Santa Maria de Roses i Sant Feliu de Guíxols com a senyors dels seus termes; Santa Anna de Barcelona i Santa Maria de Ripoll com a senyors dels castells termenats de Palafrugell i Tossa respectivament; i Sant Pau del Maresme, sense senyoria jurisdiccional, gràcies a una donació dels senyors de Montclús; Pujol (2014): 40-41. 
cumdants. ${ }^{50}$ Ara bé, a Montpalau no seria el cas, ja que el cobrament del delme del peix canvià de mans unes quantes vegades, i va estar poc temps en poder dels vescomtes de Cabrera, senyors del castell. De totes maneres, això tampoc fou res extraordinari, i en l'edat moderna, en altres localitats, el delme del peix era cobrat per mans alienes a les del senyor jurisdiccional. ${ }^{51}$

Generalment, el delme suposava una desena part dels fruits de la producció. ${ }^{52}$ Tot i així, aquest dret adquirí més complexitat, i acabà gravant una gran varietat de productes. Cadascun dels delmes que afectaven activitats diferents, doncs, posseïa les seves característiques pròpies, que depenien de la parròquia on es recaptava el producte. ${ }^{53}$ Així doncs, en el delme del peix també trobem aquestes varietats de proporció i captació segons el terme.

Sembla que a les properes localitats de Blanes, Lloret i Tossa almenys a principis del segle xvi, el delme era d'1 de cada 12 peixos. ${ }^{54}$ De totes maneres, aquesta proporció podia variar en funció del tipus de pesca que es gravava. Així, a Lloret teòricament, les soltes pagaven $1 / 15$, les nanses i els palangres $1 / 17$ i els arts $1 / 18 .{ }^{55}$ A Sant Feliu de Guíxols, en canvi, es pagava $1 / 20$ peixos, per la qual cosa allà el delme prenia el nom de «vintè». Tot i així, si el peix es pescava dins el delmar del monestir, la proporció era d'1/12. ${ }^{56}$ Aquest dret tant es podia cobrar directament del peix ja fos un peix de cada 20 o un barril, portadora o mesura de cada 20 com del valor de la venda; 1 diner de cada 20 (cf. Taula 1). ${ }^{57}$ A l'Empordà, a la majoria de poblacions el pagament oscillava entre el 5\% i el 9\%. ${ }^{58} \mathrm{Al}$ bisbat de Barcelona, on tot el delme del peix sembla que estava en mans del bisbe i el capítol, el delme era d'1/15. ${ }^{59}$ A la ciutat de Tarragona i els seus voltants de Tamarit al cap de Rifà, però, la situació era diferent. Allà el pagament era directament monetari: els pescadors de xàvega pagaven 50 sous a l'arquebisbe i els de palangre $13 .{ }^{60}$ Un pagament similar es feia al terme

50. Mallorquí (2011): 104-106.

51. Pujol (2014): 40-41.

52. Segons els costums de Girona, el delme «est decima mensura», i la tasca «est undécima mensura». Mieres (2001): 152.

53. Mallorquí (2020): 135-137. A tal d'exemple, el carnaticum, el delme dels animals, en origen potser pagat amb un de cada deu animals nascuts al mas, acabà esdevenint en diverses poblacions un pagament en moneda.

54. És a dir, el 8\%. ACG, Pabordia de Novembre, 5.6.9, ff. 8v-9r (1537-1538); Zucchitello (2013): 103.

55. ACG, Pabordia de Novembre, 5.6.9, ff. 8v-9r. Val la pena remarcar que aquesta informació s'ha extret d'un plet entre els pescadors i l'arrendatari dels drets de la Pabordia de Novembre a Lloret, i que els pescadors neguen totes aquestes proporcions, declarades pel paborde. Afirmen, però, que les soltes a dia d'avui «pagan sens nombre», és a dir, no se'ls fa un cobrament proporcional sobre la pesquera.

56. ACA, ORM, Monacals-Hisenda, vol. 1596, f. 13r (1557-1560). En aquest cas també es tracta d'un plet. Llegint els testimonis podem comprovar que, per les declaracions, el més acostumat era pagar una vintena part del peix, i no mencionen aquest pagament del peix de dins el terme. A Sant Feliu no pagaven delme els arts següents: canyes, nanses, mornells, soltes, gavitanes, gavitans, armellades, fluixes, volantins, fitores i palengronets; ACA, ORM, Monacals-Hisenda, Lligalls grans, 38 (1600 juny 27$)$.

57. ACA, ORM, Monacals-Hisenda, vol. 1596 (1557-1560).

58. Pujol (2014): 40-41.

59. Ortí (2000): 422.

60. AHAT, Arquebisbe, «Libre de les rendes pertanyents al senyor archebisbe de Tarragona en son archebisbat del any MCCCCXXXXVIII», f. 10r.; Recasens (1997): 71. 
del castell de Sant Esteve de Mar, on es cobraven 2 sous per any i per barca, encara que només pesquessin un dia, així com un quarter del peix de tall. ${ }^{61}$

\section{Taula 1}

Delme del peix a la Marina de la Selva nord

\begin{tabular}{|l|l|c|}
\hline Localitat & Què grava & Proporció \\
\hline Sant Feliu de Guíxols & $\begin{array}{l}\text { Peix pescat dins el delmar } \\
\text { (palangres i xàvegues) }\end{array}$ & $1 / 12$ \\
& Peix pescat fora el delmar & \\
& (palangres i xàvegues) & $1 / 20$ \\
\hline Tossa & Tots els arts & $1 / 12$ \\
\hline Lloret & Xàvegues & $1 / 12$ \\
& Soltes & $1 / 15$ \\
& Nanses i palangres & $1 / 17$ \\
& Art & $1 / 18$ \\
\hline Blanes & Tots els arts & $1 / 12$ \\
\hline
\end{tabular}

Font: Antoni Ginot, 2021

Al terme del castell de Montpalau hi ha documentats per primer cop els drets sobre la pesca en una donació de 1224. El 6 de gener d'aquell any, Guillem Umbert de Montseny, senyor dels castells de Ses Agudes, Miravalls, Montclús i que encara mantenia alguns drets al castell de Montpalau, de domini dels Cabrera, fa donació al monestir de Sant Pau del Maresme de tot el que ell rep en peixos i llenya com a senyor. Com hem dit, Sant Pau no tenia la condició de castell termenat, ni tampoc senyorejava un terme pròpiament dit. Ara bé, Guillem Umbert, amb la donació de 1224, estableix el que els documents del monestir anomenen el terminus franquesie. ${ }^{62}$ Era un espai comprès entre la Roca de la Cabra i la del Farell «et infra mare per duo miliaria infra prefatas duas rupes et totum quod ego babeo et accipere debeo a podio de Gerundella usque ad prefatas ruppes et usque ad mare». ${ }^{63}$

Com s'ha dit, el delme del peix sol pertànyer al senyor jurisdiccional d'un terme, un dret lligat al castell termenat. Però, com molts altres drets, no acaba essent més que un rèdit alienable, i en el cas de Montpalau aquesta sembla que acabà sent la norma. Com s'ha esmentat, a Sant Pau se li volgué donar la condició de castell, però en realitat mai va comptar amb un terme ni amb els drets que li haurien pertocat com a tal. ${ }^{64}$

61. Aquest castell es troba actualment al municipi de Palamós; Mallorquí (2008): 44.

62. Franchisia, segons el Glossarium mediae et infimae latinitatis, és el districte o territori on s'han donat certs privilegis o drets; Du Cange, et. al. (1883-1887).

63. ACA, ORM, Monacals-Hisenda, vol. 2103, f. 4v.

64. Segons els costums de Girona aquests eren so de corn, guaita, bada, obres al castell, pau i guerra, toltes i qüèsties, a més d'altres drets com la peça de peix de tall, de què en parlarem més endavant. Mieres (2001): 159-163. 
De totes maneres, sembla que aquesta donació dels Montseny de 1224, que responia al delme del peix, fou respectada, fins i tot quan els Cabrera obtingueren la plena potestat sobre el castell de Montpalau. Tampoc el canvi de mans del monestir en favor de Guillem de Montgrí el 1265 ni als cartoixans el 1270 extingiren un dret que havia quedat lligat al monestir castell. Tal cosa queda demostrada el 1271, quan es redacta una composició entre el prior i els pescadors sobre el delme del peix, amb la qual es fa palès que el dret se seguia cobrant dins els límits de la donació dels Montseny. ${ }^{65}$ Aquests drets sobre la pesca, a més, foren confirmats amb una butlla papal el $1289 .{ }^{66}$

La composició de 1271 fa constar que sorgeix arran d'un conflicte entre el prior, Anselm, i el capellà de Sant Cebrià i els pescadors, encapçalats per un tal Francesc de Cruanyes. ${ }^{67}$ En ella s'explica de quina manera es cobra el delme. D'una banda, es parla del peixos grossos, tema que tractarem amb més detall en l'apartat del peix senyoriu, ja que, tot i no ser anomenat com a tal en la composició, hi manté més similituds en la manera que era cobrat. D'altra banda, es diu que «de sagenis reciperet prior et conventus quolibet die ratione servicii de piscibus quascum piscatores pro quantitate dare eis vellent». ${ }^{6} \mathrm{Sem}$ bla, doncs, que de les xarxes es cobrava diàriament una quantitat lliure, sense cap proporció delimitada d'entrada. Potser és un cobrament similar al que ja hem apuntat que es feia a Lloret sobre les captures de les soltes, que pagaven amb quantitats lliures de peix. ${ }^{69}$ Sembla prou factible considerar també que el document distingeix el cobrament de les arts de terra, que serien les sagenis, amb les arts de barca, segons la diferenciació que hem fet en l'apartat de tècniques. Aquestes barques paguen de la manera següent: «Et de barchis, si piscarentur continue darent eis, priori videlicet et conventui, piscatores de piscibus in capite $x v$ dierum secundum quod eis placuerit». ${ }^{70}$ És a dir: les barques, si pesquen de manera regular, han de pagar al monestir un cap de peix cada 15 dies. Si no poden pescar continuadament, han de pagar un cap cada tres setmanes o cada mes, segons a ells els plaurà. ${ }^{71}$ No ens hem de sorprendre davant aquests pagaments tan laxos, de fet són una mostra de la gran càrrega simbòlica que comportaven els drets senyorials i de l'existència d'un vincle jurídic i polític entre senyor i vassalls pescadors. ${ }^{72}$ El pagament d'un cap de peix implica el reconeixement que el pescador fa de la figura del seu senyor. De totes maneres, aquest pagament amb trossos de peix es vincula més amb el peix senyoriu.

Nogensmenys, cal constatar alhora que la composició de 1271, a banda de remarcar com es fan els pagaments de les exaccions sobre la pesca, també posa els pescadors sant-

65. ACA, ORM, Monacals-Hisenda, vol. 2103, f. $24 v$ (1271 abril 9).

66. ACA, ORM, Pergamins de Santa Maria de Montalegre, 745 (1289 agost 1); Transcripció i edició a: Schmidt, Sabanés (2016): 584-586.

67. No queda gaire clar el paper del capellà de Sant Cebrià, Deudat, però no deixa de ser un fet molt interessant el seu posicionament a favor dels pescadors. ACA, ORM, Monacals-Hisenda, vol. 2103, f. $24 \mathrm{v}$ (1271 abril 9).

68. Sagenis fa referència a les xarxes; ACA, ORM, Monacals-Hisenda, vol. 2103, f. $24 \mathrm{v}$ (1271 abril 9).

69. Cf. Nota 55; ACG, Pabordia de Novembre, 5.6.9, ff. 8v-9r.

70. ACA, ORM, Monacals-Hisenda, vol. 2103, f. $24 \mathrm{v}$ (1271 abril 9).

71. ACA, ORM, Monacals-Hisenda, vol. 2103, f. $24 \mathrm{v}$ (1271 abril 9).

72. Zug Tucci (1983): 426. 
polencs sota la protecció del prior i el monestir: «Et quod dictos prior et conventus custodiret et deffenderet piscatores ne aliqua persona faciat eis iniuriam». ${ }^{73}$

La següent notícia sobre el delme del peix a Montpalau la trobem el 1332, uns quatre anys després de l'obtenció de tota la potestat del castell de Montpalau per part dels Cabrera. El 18 de maig d'aquell any, el bisbe Gastó de Girona donà en feu a Bernat de Cabrera, com a senyor de Montpalau, el delme dels peixos, olives i roldor de tot el terme del castell, en tota la seva extensió. A canvi, el vescomte ha de pagar 200 sous anuals. ${ }^{74}$ Havíem dit, però, que el delme del peix de Sant Pol havia estat donat pels Montseny al monestir, i ara és el bisbe qui l'atorga al senyor del castell. Això es deu a la política dels bisbes gironins d'obtenir el control sobre els delmes dels laics. Com diu Mallorquí, aquest control s'inicià probablement cap al segle xir i, a través dels mecanismes del feudalisme, els bisbes esdevingueren senyors de gran part d'aquests delmes. ${ }^{75}$ Així doncs, en el cas de Montpalau es produeix aquesta donació del delme en tant que feu atorgat pel bisbe al vescomte. ${ }^{76} \mathrm{~A}$ més, aquest delme comporta, com hem dit, un pagament anual de 200 sous. Tal cens respon a la voluntat dels bisbes de contrarestar la pèrdua d'ingressos de terços i lluïsmes dels delmes en mans de laics, sovint donats a institucions i beneficis. ${ }^{77}$

És precisament a les mans d'una institució on acaben els delmes del peix, olives i roldor de Montpalau: l'hospital d'Hostalric. Ara bé, abans, i almenys durant uns quatre anys (entre 1336 i 1340), aquests delmes estigueren en mans de Pere de Muntanyà per donació de Bernat de Cabrera, en atenció als seus serveis llargament exercits. El vescomte havia fet donació a Muntanyà, el seu majordom, de la batllia i el redelme del terme de Montpalau el 1335, donació que complementà un any després amb els delmes ja esmentats. ${ }^{78}$ El 1340 , però, es comença a erigir l'esmentat hospital. És aleshores quan es decideix assignar els delmes de peix, roldor i olives del terme per a la seva construcció i el seu manteniment. ${ }^{79}$ A més, el delme també ha de servir per fundar una capella i un presbiterat sota la invocació de Sant Bartomeu, així com permetre al capellà proveir l'hospital i donar de menjar als dominics i franciscans transeünts per la vila. Tal assignació és ratificada pel bisbe de Giro-

73. ACA, ORM, Monacals-Hisenda, vol. 2103, f. 24v (1271 abril 9).

74. ADM, Cabrera i Bas, lligall 10, n. 73 (AHH, Cabrera i Bas, 3147).

75. Mallorquí (2011): 165-166.

76. Mallorquí (2011): 167.

77. Mallorquí (2011): 172 .

78. ADM, Cabrera i Bas, lligall 10, n. 74 (AHH, Cabrera i Bas, 3148) (1335 febrer 20); ADM, Cabrera i Bas, lligall 10, n. 74 (AHH, Cabrera i Bas, 3148) (1336 setembre 27). Muntanyà, ciutadà de Barcelona, és el primer majordom documentat de la casa de Cabrera, precisament en aquest document de donació de delmes. Martínez Giralt creu que exercí el càrrec fins a 1329, quan és ostentat per Francesc Ferrer; Martínez (2012): 51-52; Martínez (2015): 526-527.

79. En el cas de construccions o obres a esglésies i altres edificis fou normal donar permisos per pescar en festius, assignant els guanys de part de les pescades a aquestes, és l'anomenat «peix de l'obra». El documentem el 1488 a Blanes per tal de poder decorar l'església i comprar una custòdia de plata; ADG, Lletres, U-175, f. 137 (1488 abril 30); i el 1591 a Sant Feliu de Guíxols, en benefici del temple parroquial; ADG, Notularum, G-85, ff. 125-128v (1591 maig 30). El cas més similar, però, és el de Lloret, on el 1460 es reben els beneficis de la pesca en festius per erigir l'hospital de pobres; SAMLM, Fons de la universitat de Lloret, n. 3 (1460 setembre 18). 
na, senyor del delme. Els esmentats delmes van passar a ser percebuts per la institució i el seu administrador. ${ }^{80}$

El cobrament d'aquest delme per l'hospital d'Hostalric queda confirmat al Llibre verd dels feus. En la descripció del repartiment dels delmes de Santa Maria i Sant Pere de Pineda es diu que «Hospitale de Hostlaricho recipit totam decimam ipsarum parrochiarum de oleo et de rodor et etiam de piscibus maris dictarum parrochiarum». ${ }^{81}$ Ara bé, a les parròquies de Sant Iscle i Sant Cebrià de Vallalta, les altres on es pescava, no es fa menció d'aquest delme. Pel que fa al cobrament de delme del peix pel monestir de Sant Pol, cal dir que desapareix completament de la documentació del segle xIv, i no hi ha cap mostra de conflictivitat pels drets sobre la pesca un cop el bisbe dona el delme als Cabrera. Així doncs, en la documentació sobre la venda del monestir a Bernat Joan de Cabrera el 1434 no es fa cap menció dels drets sobre la pesca. ${ }^{82}$

Durant el segle xv, però, els Cabrera recuperen el delme del peix d'aquest terme. En una àpoca de 1403, constatem que Pere Mollet, batlle de Blanes per Bernat de Cabrera, reconeix a Nicolau de Rouregros, apotecari de Blanes i collector i arrendatari dels ribatges de la mar dels termes dels castells de Blanes, Palafolls i Montpalau, que aquest li ha pagat 90 lliures i 4 diners que són el primer pagament dels ribatges. ${ }^{83} \mathrm{Si}$ per ribatge s'entén el delme del peix, doncs, en aquest cas veiem que ja és cobrat per un agent dels vescomtes i no de l'hospital. De totes maneres, només uns anys abans, el 1392 fou a Bernat Jalpí a qui Pere Mollet vengué els ribatges, en aquest cas encara eren només de Palafolls i Blanes. ${ }^{84}$ Més endavant, a les Denuntiationes decimarum del bisbe de Girona es palesa altre cop el canvi de mans. Allà, de manera similar a com s'havia fet amb el Llibre verd, uns inspectors entrevistaren individus de diferents parròquies sobre el cobrament de delmes. En aquest cas tenim testimonis del cobrament a les parròquies de Santa Maria de Pineda, Sant Cebrià i Sant Iscle de Vallalta. En totes tres s'afirma que l'hospital d'Hostalric cobra el delme del roldor i les olives, així com a la parròquia de Sant Martí d'Arenys. Ara bé, també s'indica a Pineda i Sant Cebrià que «Tot lo delme del peix de les dites parròquies pren lo vescomte

80. ADG, Mitra, 111 12, c. 12, n. 14 (1340 desembre 3) (còpia de 1554); ADM, Cabrera i Bas, lligall 10, n. 73 (AHH, Cabrera i Bas, 3147) (1341 octubre 11). El juny de 1346 encara no s'havia acabat l'hospital i el bisbe donà un termini de tres mesos per finalitzar-lo; ADG, Lletres, vol. U-10, f. 66v (1346 juny 21).

81. ADG, Mitra, c. 5, Llibre verd dels feus, ff. 142v-143r; Transcripció i edició a: Mallorquí (2011): 375.

82. ADM, Cabrera i Bas, lligall 11, n. 85 (AHH, fons Cabrera i Bas, 3264 ) (1434 agost 27).

83. AHG, notarials, Blanes 387, f. 20r. «Ribatge» és un terme utilitzat també per designar el delme del peix. Pujol i Garrido afirmen que és el nom que pren quan el dret és obtingut per laics; Pujol (2014): 34; Garrido (2011): 51. Tot i així, la Sagristia Major, una institució eclesiàstica, el percebia com a «arribatgiis de piscibus»; AHG, Vall d'Aro 274 (1394-1396). El ribatge, en origen, designava una exacció sobre el tragí de mercaderies per mar a un terme, per la qual cosa afectava igualment la pesca; Martínez (2010): 11. Així doncs, a Blanes i Palafolls s'arrendava conjuntament amb el delme del peix, tot i que hi veiem com s'hi especificava «ribaticum sive ribatge et decimam piscium» donant a entendre que, en el fons, eren dos drets diferenciats, si bé amb «ribatge» s'acabava entenent també la càrrega sobre el peix; ADM, Cabrera i Bas, lligall 21, n. 33 (AHH, Cabrera i Bas, 4136) (1491 abril 20-1557 abril 19). En un procés d'informació sobre la disminució de les rendes a Blanes, els testimonis es refereixen al dret sobre la pesca com a «ribatge»; ADM, Cabrera i Bas, lligall 44, n. 1 (AHH, Cabrera i Bas, 5466) (1412).

84. Aragó (1974): 179. 
de Cabrera» $\mathrm{i}$ «Decima piscium est tota dictu domini vicecomittum» ${ }^{85}$ Consultant els arrendaments dels ribatges i delme del peix també constatem que els Cabrera en tenien la potestat sobre Montpalau, almenys als anys 1513 i $1519 .{ }^{86}$

El 1520, però, aquest dret fou restituit a l'hospital. Sabem, pel document de la restitució, que es feu a petició dels jurats d'Hostalric, administradors de l'hospital. Així mateix, els vescomtes afirmen que ells i els seus predecessors tenien aquest dret «a magno tempore» i que cada any pagaven 10 lliures. ${ }^{87}$ Tot apunta, doncs, a una apropiació d'aquest dret ja a principis del xv. D'aquesta manera, el 1589 tornem a tenir notícia de l'hospital d'Hostalric cobrant-lo altra vegada. El 2 de maig d'aquell any, Damià Andreu, procurador de Joan Prats, rector de Sant Pere de Riu, firma un rebut de 2 lliures en concepte de ribatge a Pere Simon, administrador de l'hospital. ${ }^{88}$ Tal cosa ens mostra, doncs, que l'hospital igualment arrendava el delme, de la mateixa manera que solien fer els Cabrera.

L'apropiació del delme del peix pels Cabrera no fa estrany tenint en compte la importància del dret en les senyories costaneres. Tan important devia ser que tots els blanencs entrevistats el 1412 coincideixen a afirmar que la disminució de rendes dels vescomtes a Blanes és deguda a les males pescades dels darrers anys. ${ }^{89}$

Més enllà del segle xvi, sabem que el 1614 l'hospital seguia cobrant el dret. ${ }^{90} \mathrm{~A}$ més, els segles xviI i xix l'hospital hagué de fer front a la conflictivitat pròpia del moment, quan molts pescadors es manifestaren contraris a pagar-lo, i que en localitats com Lloret acabà en alçaments: la coneguda revolta dels Joseps. ${ }^{91}$

85. ADG, Mitra, 1115, c. 5 , n. 25 , ff. $44 \mathrm{v}-45$ r.

86. AHG, Blanes 27, f. 45 (1513 maig 8); ADM, Cabrera i Bas, lligall 21, n. 33 (AHH, Cabrera i Bas, 5466) (1519). És interessant el fet que entre 1513 i 1539 l'arrendador d'aquests drets és sempre Joan Daví, calceter blanenc, o bé el seu fill, també anomenat Joan.

87. AHG, Notarials, Blanes 45bis, f. 104v. En el mateix volum s'hi troba solta una carta feta a Girona amb data de 22 de juny de 1825 dirigida a un tal Fontanella, a qui es demana que faci mirar si als volums notarials de Joan Camps, notari de Blanes, hi ha un document amb data de 13 d'octubre de 1520 pel qual Fadrique Enríquez de Cabrera restitueix els ribatges i delmes del peix de Montpalau a l'hospital d'Hostalric, i que en cas afirmatiu en faci còpia autèntica.

88. ADG, Notularum, G-83, f. 173 r.

89. ADM, Cabrera i Bas, lligall 44, n. 1 (AHH, Cabrera i Bas, 5466) (1412 gener 17-20).

90. ADM, Cabrera i Bas, lligall 12, n. 56 (AHH, fons Cabrera i Bas, 3364) (1614 setembre 26).

91. El 1751 l'administrador de l'hospital requerí al subdelegat de Marina de Calella que fes complir l'ordre del rei de fer pagar als pescadors matriculats «el expresado derecho nombrado ribatge, que es notorio que es el diezmo de pescados, segun la cosa y en la forma que se ha acostumbrado»; ADM, Cabrera i Bas, lligall 12, n. 64 (AHH, Cabrera i Bas, 3372) (1751 maig 26). Onze anys després, sembla que els pescadors de Palafolls declaraven que havien de pagar el delme del peix pescat allà a l'hospital. Tot i així, es van fer les investigacions adeqüades per determinar que el ribatge de Palfolls pertanyia al duc de Medinaceli i no a l'hospital d'Hostalric, que el cobrava a Montpalau. En la carta redactada amb els informes de la recerca no s'hi indica cap més document que no hagi estat utilitzat en aquest article; ADM, Cabrera i Bas (AHH, Cabrera i Bas, 532). La conflictivitat seguí durant uns quants anys, i el 1804 es promulgà una resolució reial que obligava els pescadors de Sant Pol a seguir pagant el delme del peix a l'hospital; Zucchitello (2011): 341. 


\section{El castellatge del peix}

El castellatge del peix era un dret cobrat pels titulars de les castlanies dels castells termenats, en origen com a remuneració per exercir les funcions de castlà. És un dret que no ha estat gaire estudiat i es troba poc en la documentació.

Els castlans cobraven alguns drets cedits pels senyors dels castells de qui eren vassalls. Trobem cobraments de parts de delmes i drets específics anomenats castellatge. Per exemple, a Tossa el castlà cobrava un castellatge dels masos en forma de cereal. ${ }^{92} \mathrm{O}$ el castellatge pagat sobre els animals al vescomtat de Cabrera. ${ }^{93}$ Ara bé, en diferents localitats de la Selva hem pogut identificar el cobrament d'un dret sobre el peix anomenat també castellatge. Tots els termes on es documenta comparteixen un fet: són termes castrals i s'hi documenta l'existència de castlania. Els termes on no hem pogut documentar el castellatge del peix són, precisament, Sant Feliu de Guíxols i Fenals d'Aro, probablement perquè no formaven part de cap terme castral pròpiament dit. Tampoc l'hem documentat a Palafolls, però encara cal fer més recerca en aquest punt.

Entre els pobles on es documenta el castellatge, a Solius, al capbreu de la Sagristia Major de la seu de Girona s'especifica, en les declaracions d'Eligi Ferrer, ferrer del terme, el cobrament de l'«arribatgiis seu castellagiis de piscibus». ${ }^{44}$ Allà es documenten castlans, per bé que al segle xv possiblement ja es tractaven d'oficials menors. ${ }^{95}$ Tal cosa podria fer pensar que la Sagristia podia haver adquirit els drets de la castlania, quelcom gens estrany entre els senyors de castells. ${ }^{96}$

Tossa és un dels termes on més bé es documenta aquest dret. Gràcies a la preservació del fons patrimonial dels batlles i castlans de Tossa, la família Riera, que adquirí la batllia el $1371 \mathrm{i}$ la castlania uns anys abans, podem conèixer com cobraven el castellatge. ${ }^{97} \mathrm{El} 1420$ capbrevaren la castlania i tots els drets que portava associats, entre els quals el castellatge del peix, al seu senyor eminent, l'abat de Ripoll. A canvi d'aquest pagament, el castlà es comprometia a fer foc, residència contínua i personal al castell i guardar-lo, així com fer guaita i bada.$^{98} \mathrm{El} 1507$, una sentència arbitral confirmava el dret, i també l'obligació del batlle-astlà de complir les seves funcions, en les quals s'havia relaxat els darrers anys. Ja en aquest plet es destaca que el dret es cobra sobre els «piscibus qui recipiuntur in plagia et termino de Tussia ab exavega e ab art de pescar que manualment se tira en terra». ${ }^{99} \mathrm{El}$ castellatge, a Tossa, era «segons fins assí se és acostumat pagar al dit Riera e als seus pre-

92. Sabaté (1993): 191-192; Zucchitello (2013): 111-112.

93. ADM, Cabrera i Bas, lligall 37, n. 2 (AHH, Cabrera i Bas, 5319).

94. AHG, notarials, Vall d'Aro 274, f. 81r.

95. Aicart, Auladell, Vivo (2010): 59; Marcó (2011): 191.

96. Les castlanies esdevingueren, a la baixa edat mitjana, un grapat més de drets a incorporar pels senyors; Sabaté (1993): 188-189; Pons Guri (1989): 527.

97. Zucchitello (2013): 64. L'adquisició de castlanies per part de vilatans benestants no era estrany a la baixa edat mitjana; Sabaté (1993): 189.

98. Zucchitello (2013): 111.

99. AAT, Secció Falguera, Caixa I, n. 49, ff. 12r-12v. 
decessors» d'1 peix de cada 25, o bé de malla (1/2 sou) per sou en cas que s'hagués venut. A més, en Riera no podia cobrar el castellatge de més d'un bol per companyia. ${ }^{100}$ El títol de castlà, però, desaparegué de la documentació de Tossa el 1639 amb l'abandonament del castell, i amb ell el castellatge, perquè es cobrava per exercir unes funcions respecte al castell que ja no es podien complir. ${ }^{101}$

Lloret és l'altra població on es documenta, igualment prou bé, el castellatge del peix. Era cobrat pels cavallers Lloret, castlans del castell de Sant Joan, que el vengueren el 1372, juntament amb la castlania, la meitat del delme del peix i diversos drets sobre masos, a la Pabordia de Novembre, tot plegat tingut ja abans de la venda en feu seu. ${ }^{102}$ Sabem que el segle xvi se seguia cobrant aquest dret, pagat amb visos, verats i/o sorells. ${ }^{103}$ El 1537 s'especifica que la proporció sobre la pescada era d'1/25 i es cobrava sobre les xàvegues. ${ }^{104}$

En el mateix document de Lloret de 1537, es diu que aquest dret era cobrat també a Tossa i Blanes. En aquesta darrera població tenim identificada, ara per ara, només una única referència. En unes ordinacions amb data de 23 d'agost de 1436, el comte de Mòdica, i vescomte de Cabrera, Bernat Joan de Cabrera, ordena que «lo dret de castell que és semblant dret com lo delme, sie relexat a tots e sengles exavaguers, e a totes e sengles altres persones qui pescaran en lo dit temps en lo lloc apellat de Savanell e en les mars de Blanes». ${ }^{105}$ És possible que aquest castellatge, o dret del castell, es trobés entre les rendes del castell, que s'arrendaven, ${ }^{106}$ tot i que a Blanes es documenten diversos castlans que potser cobraven castellatge, com ara Guillem Sala el 1400-1402, Pere Durall el 1411 o Antoni Sabet el 1458. ${ }^{107}$

A Palafolls no hi ha rastre d'aquest dret de castellatge. Si més no hi apareix un «castlanus maris» que es devia encarregar de la vigilància del litoral del terme i dels cobraments dels drets. ${ }^{108}$ En canvi, a Montpalau sí que s'ha documentat. ${ }^{109}$ La primera menció és també una donació al monestir de Sant Pau. De la mateixa manera que els Montseny havien donat tot el que rebien com a senyors en peixos i llenya al cenobi el 4 de gener de 1224, els Montpalau, castlans, fan el mateix un dia després. El 5 de gener de 1224, Ponç de Montpalau i Raimunda, la seva esposa, donen a Sant Pau «totum hoc quod accipimus et accipere debemus ratione castelanie, vel alio modo, tam in picibus quam in lignis» dins el terme de Sant Pol ja delimitat pels Montseny. ${ }^{110}$

100. AAT, Secció Falguera, Caixa I, n. 49, ff. 13r-15v.

101. Zucchitello (2013): 111.

102. SAMLM, Universitat de Lloret, n. 72 (1372 març 2); Transcripció i edició a: Pons Espó (2002): 35-45.

103. ACG, Pabordia de Novembre, 5.5.1, ff. 3r-6v (1506).

104. En el document és anomenat «dret de castell»; ACG, Pabordia de Novembre, 5.6.9, f. 8v (1537).

105. Aquest dret era arrendat a Blanes, com la majoria de drets sobre la pesca; ADM, Cabrera i Bas (AHH, Cabrera i Bas, 4835) (1436 agost 23).

106. ADM, Cabrera i Bas, lligall 44, n. 1 (AHH, Cabrera i Bas, 5466), f. 6v (1412 gener 17).

107. Talment sembla un càrrec que anà passant per mans de diversos vilatans; Aragó (1974): 185; AHG, notarials, Blanes 6, ff. 55r-55v (1400 febrer 25); AHG, notarials, Blanes 420, f. 20r (1458 agost 31).

108. AHFF, Notarials, Palafolls 551, f. 10v (1399 octubre 13).

109. Al Baix Maresme també es documenta un dret dels castlans sobre la pesca al castell de Mataró, consistent en el pagament de 12 diners per barca; Subiñà (2015): 153.

110. ACA, ORM, Monacals-Hisenda, vol. 2103, ff. 5r-5v (1224 gener 5). 


\section{Mapa 2 \\ Castells termenats on els castlans cobraven el castellatge o un dret similar}

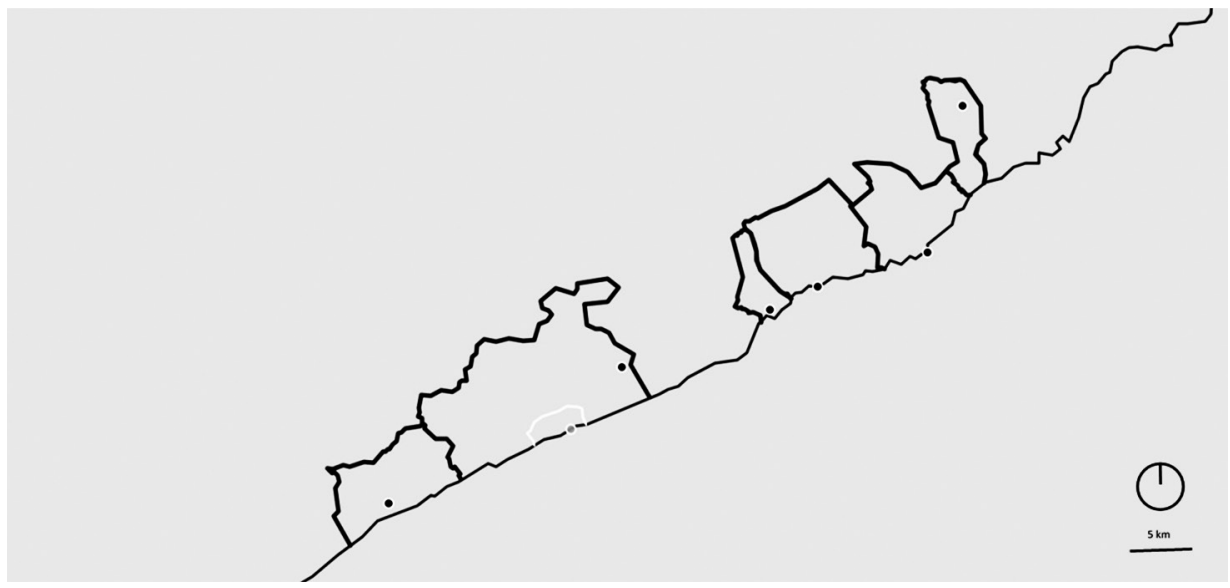

D'esquerra a dreta, en negre: Castells de Mata, Montpalau, Blanes, Lloret, Tossa i Solius. En blanc, el terminus franquisie del monestir de Sant Pau (Instamaps. Antoni Ginot, 2021).

Aquest dret de castlania sobre els peixos donat al monestir reapareix el 1271 en la composició amb els pescadors, en la qual es diu que, dels peixos grossos, «ratione castlanie reciperet monasterium seu prior et conventus Sancti Pauli caput et ratione domini carterium» («per raó de castlania que rebin el monestir o el prior i convent de Sant Pau el cap i per raó de senyoria un quarter»). ${ }^{111} \mathrm{Si}$ bé en els altres casos hem dit que el castellatge suposava 1/25 part dels peixos, en aquesta ocasió es cobra amb una part del peix gros. Així doncs, tornem a constatar la dimensió simbòlica d'aquestes exaccions. Aquí s'observa una fusió amb el peix de tall, o peix senyoriu, tot i que, com veurem, aquest dret també era cobrat simultàniament per raó de domini. És a dir, que el monestir gravava els peixos grossos per raó de drets provinents de dos títols: el de domini, és a dir, el del senyor jurisdiccional, i el de castlania, donats pels seus titulars respectius el 1224.

Amb tot, hem d'entendre que el dret dels castlans sobre el peix de Montpalau era cobrat per ells mateixos, o per mans del seu batlle, ${ }^{112}$ en les parròquies de Sant Martí d'Arenys, Sant Iscle de Vallalta i Santa Maria de Pineda, i pel monestir de Sant Pau, gràcies a la donació, al litoral de la parròquia de Sant Cebrià. Així doncs, com ja hem apuntat, la castlania de Montpalau va ser venuda per Arnau de Pontons a Ramon de Cabrera el 1294, juntament amb tots els drets que aquesta comportava «tam in terra quam in

111. ACA, ORM, Monacals-Hisenda, vol. 2103, f. $24 \mathrm{v}$ (1271 abril 9).

112. A Montpalau existia una batllia que, almenys en la dècada de 1330, s'anomena «de castlania"; Martínez (2015): $441-442$ 
mari». ${ }^{113}$ A partir d'ara, qui rebé el castellatge del peix fou el vescomte de Cabrera. Així ho demostra un altre document inserit al llibre de privilegis del monestir. El 18 de desembre de 1339, Bernat de Cabrera absol tots els pescadors de barca de la baronia de Montpalau de tot el castellatge dels peixos: «Totum castelatge sive donum piscium et quidquid et quantum racione dicti castelatge sive donum recipimus seu recipere consuevimus de picibus (sic) seu ratione piscium qui capiuntur cum barchis per piscatores termini supradicti». ${ }^{114}$

És interessant veure com el document diu que aquesta absolució «non intelliguntur sagene vel exavegue». Per tant, sembla que aquests arts xarxes i xàvegues han de seguir pagant el castellatge, de la mateixa manera que hem vist que es feia a Lloret i Tossa, on el castellatge gravava només les xàvegues. De manera similar devia passar a Blanes, on, com hem vist, el pagament afecta només aquest tipus d'art. ${ }^{115}$ Així doncs, Bernat de Cabrera, perceptor de les rendes de la castlania, té la potestat de suprimir el dret. Resulta interessant veure com els cartoixans decideixen copiar aquesta absolució al seu llibre, potser ells tampoc cobraven el dret als pescadors de barca? Seguien tenint, doncs, la potestat sobre aquest dret, però lligada a la voluntat del senyor del castell? Entenem que és factible pensar que si inclogueren el document fet pel vescomte en el seu cartulari és perquè també calia que ells deixessin de cobrar el dret de castellatge sobre la pesca de barca.

En el mateix text es constata, a més, que els oficials dels vescomtes s'estan excedint cobrant peixos a les xàvegues, sobre els quals diuen que hi tenen dret: «de dictis piscibus capiendi ut dicitur ius habere intendent». El vescomte, doncs, els prohibeix de fer tal cosa, a no ser que els pescadors vulguin oferir-los peix per voluntat pròpia. ${ }^{116}$

D'altra banda cal remarcar la data: 1339 és un any abans que Bernat de Cabrera cedeixi tot el delme del peix a l'hospital d'Hostalric. No tenim cap més pista, però, ni de l'origen d'aquesta decisió ni de si estava lligada a la donació del delme. De totes maneres, podem entendre que no es devia treure gaire profit del castellatge de les barques, que segurament pescaven amb palangres o nanses, una pesca de poques captures. De la mateixa manera que com a delme només se'ls exigeix un cap de peix. Amb tot, doncs, interessa mantenir la presència senyorial amb aquest simbolisme. Així, és possible que resultés ja prou profitós cobrar el castellatge només de les xàvegues, l'art més difós i productiu.

Molt probablement, el castellatge es deixà de cobrar a Montpalau el 1486, ja que la Sentència Arbitral de Guadalupe establia que se suprimien tots els «censos i castellanies i guaytes» dels castells enderrocats. ${ }^{117}$

113. ADM, Cabrera i Bas, lligall 10, n. 65 (AHH, Cabrera i Bas, 3138) (1294 maig 20).

114. ACA, ORM, Monacals-Hisenda, vol. 2103, f. 25 r (1339 desembre 18).

115. ADM, Cabrera i Bas (AHH, Cabrera i Bas, 4835) (1436 agost 23). Per contra, a Mataró, com hem dit, són les barques les que paguen dret de castlania; Subiñà (2015): 153.

116. ACA, ORM, Monacals-Hisenda, vol. 2103, f. 25r (1339 desembre 18).

117. ACA, Cancelleria, Registres, 3549, ff. 162v-163r. 


\section{El peix senyoriu}

El peix senyoriu, peix de tall o peix reial era la manera de designar el dret que afectava unes espècies de peix en concret. Normalment, aquests peixos eren esturions, tonyines, emperadors i dofins igualment considerats peix. ${ }^{118} \mathrm{Amb}$ tot, eren espècies d'una grandària considerable i amb un important valor simbòlic.

Aquest dret consistia normalment en el cobrament d'una part del peix, un tall. Per exemple, a Sant Feliu, el 1181, es cobrava una meitat dels peixos. Dels peixos espasa, la meitat del mig en amunt, i de les tonyines la meitat d'un tall transversal de cap a cua; la resta de peixos es tallaven pel mig i es donava la part de la cua. A canvi, però, el monestir donava blat i vi als pescadors en compensació per dur-hi el peix. ${ }^{119}$ El 1557, l'abat de Sant Feliu de Guíxols encara seguia prenent la meitat del peix més gros de cada pescada, tal com s'havia estipulat el 1393. A més, de la resta de tonyines, que no fossin la més grossa, calia pagar un diner per cadascuna, 3 en cas que fossin pescades amb tonaira. ${ }^{120}$ A Palamós, en canvi, el bisbe de Girona, senyor de Vila-Romà, cobrava només $1 / 4$ del peix de tall. ${ }^{121} \mathrm{~A}$ Roses, però, es cobrava un de cada 3 peixos grossos de cada bol de pesca, ${ }^{122}$ i a Tarragona, del peix espasa, el dofí i l'emperador se'n feien 5 parts havent-ne tret cap i cua, 3 parts eren per al rei, una per a l'arquebisbe i una per al paborde. ${ }^{123} \mathrm{~A}$ la Selva es documenta a Tossa el 1186; a Lloret al segle xiv, on es pagava el peix de tall i un sou de cada 30 de les tonyines pescades, i a Blanes també. ${ }^{124} \mathrm{En}$ aquesta localitat sabem que hi havia un dret que afectava bàsicament els dofins capturats i morts en tota la mar del seu terme. ${ }^{125}$

A vegades aquesta exacció sobre el peix de tall sembla que es confon amb el delme del peix, de manera que passa a ser considerada, doncs, una manera específica de gravar aquestes espècies més grans amb el delme. Per posar un cas, al Llibre verd dels feus, quan es fan les declaracions de Vila-Romà, es diu que Pere Pallarès, senyor del castell de Sant Esteve, cobrava «decimam piscium de tayl». ${ }^{126} \mathrm{~A}$ Sant Feliu de Guíxols el 1557 l'impagament del dret sobre unes tonyines portà a un plet que enfrontà el monestir contra un jurat i un pescador de la vila, tot i que al llarg de tot el plet es vincula aquest dret amb el del delme del peix. ${ }^{127}$

118. Pujol (2014): 36; Recasens (1997): 71.

119. Zucchitello (2013): 198.

120. ACA, ORM, Monacals-Hisenda, vol. 1596, f. 13v (1557-1560); Pujol (2018): 36.

121. Pujol (2018): 35.

122. Pujol (2014): 60.

123. Recasens (1997): 71.

124. Zucchitello (1998): 233; Mallorquí (2014): 109; ACG, Pabordia de Novembre, 5.1.1.

125. La referència prové d'una donació d'Ermessenda de Cabrera, filla de Guillem Galceran de Cartellà, cavaller de Maçanet, a favor d'Alamanda, esposa de Guillem de Blanes, de tot el dret que el seu pare i avantpassats tenien sobre els dofins; ADM, Cabrera i Bas, lligall 21, n. 8 (AHH, Cabrera i Bas, 4110). El fet que uns cavallers de la plana de la Selva cobrin un dret pesquer es deu a l'obtenció del castell de Blanes en feu, que el 1213, en el seu testament, Ermessenda de Cartellà repartí entre els seus fills Galceran (2/3 del domini) i Bernat de Cartellà (1/3). El 1296, Guillem Galceran obtingué la resta del domini, tot i que probablement el devien compartir amb els Blanes; Mallorquí (2015): 62-63; Pladevall (1972): 27-28.

126. ADG, Mitra, c. 5, ff. 50r-51r; transcripció i edició a Mallorquí (2011): 279-280.

127. ACA, ORM, Monacals-Hisenda, vol. 1596 (1557-1560). 
Tornant a Montpalau, hem pogut comprovar que els pescadors han de pagar, cada certs dies, un cap de peix. Tal dret es vincula més amb el peix senyoriu que amb el delme en tant que afecta només els peixos grossos. Ara bé, els dos drets poden haver estat identificats com un de sol, remarcant-ne així la càrrega simbòlica per sobre d'un possible benefici econòmic.

Malgrat aquesta varietat de maneres de ser cobrat i la seva identificació amb el delme, el peix de tall era un dret ben configurat, un dret per se, amb presència als costums de Girona. En aquests, es diu que els drets del castell termenat que no prescriuen eren 4: so de corn, guaita, bada i treball en obres, a més també tenien el dret de pau i guerra, toltes, qüèsties i d'altres com una peça del peix de tall que s'ha pescat a les aigües del terme, com és costum a Catalunya. ${ }^{128}$ Tal dret és vist com una prova del fet que un castell és termenat, i així s'esgrimeix en la sentència sobre el castell de Lloret de 1378:

$[\ldots]$ ítem consuevit habere in dicto castro et eius terminis [...] unam peciam piscis de tayll [...] ítem predicta consueverunt ab antiquo habere in dicto castro et eius terminis de Loreto et in possessionem vel quasi premíssorum fuerunt domini dicti castri pacifice et notorie. ${ }^{129}$

A Montpalau es diu que, dels peixos grossos, per raó de castlania, com hem vist, es cobra el cap, i per raó de domini, «carterium». Aquest quarter que es cobra és, doncs, el dret que el senyor del castell, el dominus, té sobre els peixos, que prové de la donació dels Montseny i que podem vincular directament amb el peix de tall dels Costums de Girona. Tal dret provinent de la senyoria jurisdiccional es podria considerar, per tant, el que aquí anomenem peix senyoriu. D'altra banda, el cap del peix cobrat per raó de castlania esdevé una reducció simbòlica de la remuneració del castlà. En aquest sentit, no ho consideraríem peix senyoriu. ${ }^{130}$ És a dir, es converteix en un reconeixement de les potestats que el monestir de Sant Pau té sobre els pescadors gràcies a la donació de 1224.

Amb tot, remarquem altra vegada el simbolisme que té el peix senyoriu, és a dir, el fet de cobrar una part del peix, molts cops sense valor econòmic, com el cap. Ja els senyors del moment n'eren plenament conscients i així ho descrivien a Tarragona el 1449: «La cosa és de poch profit, sinó per la pertinència». ${ }^{131}$ És inevitable vincular aquestes paraules amb el dret que cobra el monestir de Sant Pol sobre les barques de pesca: un cap de peix per barca cada 15 dies o cada mes. Una exacció que, més enllà de l'obtenció d'un benefici de la producció pesquera, esdevé una asserció del paper del cenobi sobre els pescadors. ${ }^{132}$

128. Mieres (2001): 159-163.

129. Pons Guri (1982): 99.

130. Val a dir que a la baronia d'Eramprunyà (Baix Llobregat) el castlà cobrava també una peça dels peixos grossos, de la mateixa manera que feia el senyor de Castelldefels, tot i que es remarca que aquesta exacció és cobrada per dret de castlania, i la part que s'obté per Castelldefels es cobra en tant que senyors d'aquest lloc; Cantarell, et al. (2011): 117-179, 229-232, 300-301.

131. Recasens (1997): 71.

132. Aquest tipus de pagament es reprodueix en altres zones del Mediterrani, com a Itàlia, amb protagonistes eclesiàstics i laics, que afirmen el seu domini sobre els pescadors i les seves activitats a través d'aquests cobraments simbòlics, 
Aquests drets simbòlics es poden trobar també sobre altres activitats com la caça: a Tossa es cobraven els ullals dels senglars caçats. ${ }^{133}$

\section{Conclusions}

En definitiva, hem pogut observar quins eren els drets sobre la pesca cobrats al castell de Montpalau i en podem extreure com a conclusió genèrica que plasmen uns drets de pesca fragmentats, mudables i en diverses mans. Uns drets que tenen el seu origen en la senyoria jurisdiccional, que és qui ocasionalment els aliena, tant a oficials seus (castlans, majordoms...) com a institucions sense, a priori, cap domini del litoral, els quals vol beneficiar (monestirs, hospitals...).

Primerament, doncs, destaca la desvinculació en una part del terme de certs drets de pesca del domini banal de la baronia, per ser atorgats a un monestir que no exerceix cap poder jurisdiccional en el lloc. Almenys al bisbat de Girona no hi ha gaires més mostres de segregació de termes per assignar drets de pesca a un senyor menor, sense jurisdicció en el territori, i molt probablement a la resta de Catalunya tampoc. Tot plegat, però, remarca l'interès dels monestirs a controlar la pesca i obtenir-ne un benefici. Tal fet queda llargament demostrat pels cenobis de Sant Feliu de Guíxols i Ripoll.

A més, es constata que el delme del peix entra en la mateixa dinàmica de compravenda i donacions que ja era comuna en els altres delmes i drets. La seva donació a l'hospital d'Hostalric palesa aquest fet. Així mateix, el seu retorn a mans dels Cabrera i la posterior recuperació per part de l'hospital denota que hi tenien un interès important. D'aquesta manera podem deduir que el gravamen sobre la pesca devia aportar un benefici d'una certa importància.

Cal remarcar igualment la vinculació d'aquests drets amb la senyoria jurisdiccional i, especialment, la càrrega simbòlica que impliquen. Aquest component s'aprecia sobretot amb el peix senyoriu i, en l'àrea estudiada, té molt més pes en els cobraments del monestir de Sant Pau. Caldria acabar de constatar, però, com es reprodueix en altres zones del litoral i en quines cronologies és més recurrent. A més, un obstacle important és la confusió d'aquest dret més simbòlic, com és el peix de tall, amb els altres dos documentats. Nogensmenys, més enllà de ser element de confusió, el fet també ens serveix per adonar-nos del gran simbolisme que comporten, i que remarquen en tot moment que l'accés al peix és possible gràcies a la permissivitat del senyor, amb el qual es manté un vincle jurídic i polític.

D'altra banda, cal recalcar la presència del castellatge del peix com a dret propi dels castlans. És important la seva evolució: si bé en origen era una remuneració, acabà reduint-se a una imposició més sobre la pesca, especialment a causa de la no poc freqüent adquisició dels drets de castlania per part dels senyors. Amb això, i les donacions dels drets

amb parts de peixos i animals de caça amb escàs valor alimentari però sí simbòlic. Zug Tucci (1983): 425-430; Vendittelli (1992): 409-410.

133. Zucchitello (1998): 228. Si voleu més exemples de cobraments de parts d'animals de caça i la seva anàlisi a Itàlia, cf. supra. 
a Sant Pau, podem posar els drets sobre la pesca al mateix nivell que qualsevol dret feudal, i entendre que la percepció de rendes sobre les activitats pesqueres és molt més complexa que el simple lligam amb el senyor jurisdiccional del litoral, si bé gairebé sempre és ell qui fa les donacions dels drets.

Amb tot, la importància de Montpalau i els drets de pesca cobrats rau en la fragmentació $\mathrm{i}$ la seva donació a diverses mans, fins i tot a senyories amb poc o gens poder jurisdiccional. Tal cosa fa que es marqui una distància amb els delmes del peix cobrats de manera més uniforme, per exemple, als bisbats de Barcelona o Tarragona, en mans pel que sabem ara mateix del bisbe, l'arquebisbe i la catedral. La descripció dels drets de pesca que s'ha fet en l'article també mostra una evolució des del feudalisme més originari fins a la seva conversió en drets orientats al simple guany monetari, una evolució parallela a la de la resta de drets, i que en fa una prerrogativa més del poder feudal. Amb tot, aquesta aproximació microhistòrica d'unes exaccions en concret aporta una nova base sobre la qual es poden, i es faran, futures reflexions pel que fa al significat i la importància dels drets de pesca, així com el seu paper en l'economia i la societat feudals.

A manera de conclusió general, doncs, afirmaria que a la història de la renda sobre la pesca encara li queda un bon tros per recórrer atesa la particularitat de cada terme en la percepció d'aquests drets. Esperem, doncs, que aquest estudi en sigui un pas endavant.

\section{Apèndix documental ${ }^{134}$}

\section{Composició sobre els drets de pesca de Sant Pau del Maresme}

\section{1 abril 9}

Composició feta per Guillem Lloret, prior de Santa Maria de Rocarossa, a causa del conflicte que tingué lloc entre Anselm, prior de Sant Pau del Maresme, i el monestir, contra Deudat, capellà de Sant Cebrià de Vallalta, Francesc de Cruanyes i altres pescadors, per raó dels drets sobre el peix.

O. Original: Barcelona. ACA, Ordes Religiosos i Militars, Pergamins de Santa Maria de Montalegre, 512 (233 x $160 \mathrm{~mm})$. Pergamí en bon estat de conservació, lectura difícil. A.* Còpia del segle XIV. Barcelona. ACA, Ordes Religiosos i Militars, Monacals-Hisenda, vol. 2103, f. $24 \mathrm{v}(310$ x $224 \mathrm{~mm})$. Bon estat de conservació, ex $\mathbf{O}$.

Compocitio super decimam piscium qua monasteri solebat | accipere infra termini franquesie

134. Normes de transcripció: S'ha respectat el text al màxim. Per a una millor comprensió s'han introduitt punts i a part, especialment abans de la data i signa dels actors. S'ha transcrit la $j$ com a $i$. Igualment s'han introduit apòstrofs i cometes seguint criteris actuals. Les paraules s'han unit o separat seguint també criteris ortogràfics. S'indica el salt de línia amb | i el número d'aquesta en els múltiples de 5. Les anotacions al marge s'indiquen amb nota crítica al peu, així com alguns esclariments que s'ha considerat adequat fer. Vull agrair l'ajut prestat per Glòria Torres, Daniel Piñol, Alberto Martínez i Jordi Saura a l'hora de fer les transcripcions i comprendre el text. 
| Cum ${ }^{135}$ contentio esset inter Alcelmum priorem Sancti Pauli de Maritima, et conventum dicti loci, ex una | parte, et Deusdedit, capellanum Sancti Cipriani de Valle Alta et Franciscus de Crosaneis, et quosdam alios | piscatores super piscatorem piscium ex altera, causa piscis venerunt ad compositonem in posse Guiyll | [el]mi Loreti, prioris Sancte Marie de Rupe Russa qui de consilio et voluntate percium(sic) sub pena centum solidorum. $\left.\right|^{5}$ Taliter pronunciavit quod in piscibus magnis ratione castlanie reciperet monasterium ${ }^{136}$ seu prior et conventus Sancti | Pauli, caput, et ratione domini, carterium. Et de sagenis ${ }^{137}$ reciperet prior et conventus quolibet die $\mid$ ratione servicii de piscibus quascum piscatores pro quantitate dare eis vellent. Et quo ipsi, scilicet prior $\mid$ et conventus, benignissime reciperet illud servicium a piscatoribus datum sive oblatum. Et quod dictos prior | et conventus custodiret et deffenderet piscatores ne aliqua persona faciat eis iniuriam. Et de $\mid{ }^{10}$ barchis, si piscarentur continue darent eis, priori videlicet et conventui, piscatores de piscibus in capite $\mid \mathrm{xv}$ dierum secundum quod eis placuerit, vel si nollent aut si non possent piscari continue, darent eis in capite | trium septimanarum vel mensis secundum quod eis placuerit, vel habuerint et hoc fuit approbatum ex utraque parte | et promissum quod semper observarent istud et quod inde in aliquo contravenierent per se vel per aliqua personam | interpositam iure aliquo vel ratione et si aliquo iure vel ratione possent contra revenire illi iuri vel rationi $\left.\right|^{15}$ renunciaverunt in presenti. Actum est hoc quinto idus aprilis anno Domini $\mathrm{M}^{\circ} \mathrm{CC}^{\circ}$ septuagesimo primo.

Sig + num Deusdedit, capellani Sancti Cipriani de Vallis Alta. Sig + num Francisci de Crosaneis. Sig + num | Maymoneti. Nos pariter qui hoc firmamus, laudamus, testibus firmarique rogamus.

Testes huius rei sunt Raymundo Petro Medicus et Petrus de Capiteaspero et Petro Gili.

| Ego Guillelmus prior Sancte Marie de Rupe Russa qui hac compositionem feci + subscribo

${ }^{20} \mathrm{Sig}$ (senyal) num Guyllelmi de Serra, presbiteri et ebdomedarii ac pronotarii Sancte Marie de Pineta, qui hoc scripsit die et anno quo supra.

\section{Absolució del castellatge del peix de Bernat II de Cabrera als pescadors de Montpalau}

\section{9 desembre 18}

Bernat II, vescomte de Cabrera, senyor del castell de Montpalau, absol i enfranqueix tots els pescadors del terme de Montpalau de tot el castellatge del peix que es rep dels peixos pescats amb barques. No s'inclouen en aquesta absolució les xarxes ni les xàvegues. També prohibeix als seus oficials recaptar peix de manera abusiva.

[O]. Original perdut. A*. Còpia del segle xiv. Barcelona. ACA, Ordes Religiosos i Militars, Monacals-Hisenda, vol. 2103, f. 25r (310 x 224 mm). Bon estat de conservació, ex O.

135. Nota que fa per los | pescadós de alí dir| ho an Sala, al marge i amb lletra del xVII O XVIII.

136. Signe estrany.

137. És un tipus de xarxa. 
Sit omnibus notum quod nos, Bernardus, Dei gratia vicecomes Caprarie, dominus castri de Montepalacio, per ${ }^{138} \mid$ nos et nostros presentes et futuros, gratis et excerta sciencia, absoluimus, diffinimus et remittimus et | etiam enfranchimus omnibus et singulis piscatoribus baronie termini castri nostri predicti de Monte | palacio, tam presentibus quam futuros, totum castelatge sive donum piscium et quidquid et quantum racione dicti $\left.\right|^{5}$ castelatge sive donum recipimus seu recipere consuevimus de picibus(sic) seu ratione piscium qui capi | untur cum barchis per piscatores termini supradicti. Ita quo de cetero dicti piscatores barcharum, tam | presentes quam futuri non teneantur ad prestationem dicti castelatge sive doni nec aliquid ratione ipsius. I Immo fuit a dicto castelatge seu dono et a quocumque alio quod ratione ipsius dari consuerit franqui | absolti liberi et immunes et promitimus per nos et nostros quod dictam absolutionem remissionem et $\mid{ }^{10}$ enfranquimentum ratam et firmam ac ratam et firmam semper habemus et nullo tempore | revocabimus vel contraveniemus aliqua ratione, iure vel causa. In hac absolutione, diffinitione et remissi | one non intelliguntur sagene vel exavegue. Preterea cum ad nominum provenit quorumdam relatione | auditum quod officiales nostri in termino de Montepalacio supradicto capiunt et recipiunt de piscibus | exavagarum sine solutione et satisfactione et de dictis piscibus capiendi ut dicitur ius habere intendunt. Ideo, $\mid{ }^{15}$ dicimus et mandamus quo de cetero nullus officialis noster in termino supradicto de piscibus exa | vagarum nec eciam barcharum dicti termini capiat neque tangat nec capere audeat seu presumat. Immo, | acapcione et recepcione ipsorum piscium cesset penitus et desistat nec piscatores ipsarum exavagarum | seu barcarum tam presentes quam futuri dicti termini de dictis piscibus eisdem officialibus seu eorum alicui da- | re teneantur nisi quancum de eorum processerit voluntate.

Actum est hoc quinto decimo kalendas ianuarii $\left.\right|^{20}$ anno Domini millesimo trecentesimo tricesimo nono.

Sig + num Bernardi Dei gratia vicecomitis pre | dicti qui hoc firmamus et laudamus.

| Testes huius rei sunt frater Arnaldus, prior monasterii Sancti Pauli de Maritima, Bernardus de Ma|nola, Guillelmus de Montecorvo, milites.

| Sig (senyal) num Guillelmi Sabaterii, gerentis vices Petri Flecherii, notarii publici termini ${ }^{25}$ castri de Montis Palacii, qui hec scribi fecit et clausit cum raso et rescripto in VII ${ }^{\mathrm{a}}$ linea | ubi dicitur «ac ratum et firmum» et cum suprascripto in ix ${ }^{\mathrm{a}}$ ubi dicitur «nostri».

\section{Bibliografia}

Aicart, Francesc; Auladell, Marc; Vivo, Jordi (2010). El Castell de la Roca. Les empremtes d'una fortalesa fantasma a Solius (Santa Cristina d'Aro, Baix Empordà). Santa Cristina d'Aro-Girona: Ajuntament de Santa Cristina d'Aro-Universitat de Girona, Institut de Recerca Històrica.

Aragó, Antoni M. (1974). «Els castells de Blanes i Palafolls i el vescomtat de Cabrera, el segle XIV», Annals de l'Institut d'Estudis Gironins, vol. 22, p. 177-190.

138. Fa també per los pesca| dós de St Pol, al marge i amb lletra del XVII o XVIII. 
Cantarell, Elena; Comas, Mireia; Muntaner, Carme (2011). El llibre de la baronia d'Eramprunyà, Lleida: Pagès.

Carbonell, Eliseu (2010). «Patrimoni marítim i usos socials de la platja de Sant Pol de Mar», Revista d'etnologia de Catalunya, núm. 35, p. 230-233.

Du CANGe, et. al. (1883-1887). Glossarium mediae et infimae latinitatis [en línia]. Niort: L. Favre (disponible a: < http://ducange.enc.sorbonne.fr/>) (darrera consulta: 20/10/ 2021).

Esteva, Lluís; Paluí, Lluís (1995). Els llocs de la Vall d'Aro, Gissalis i el monestir Guixolenc (881-1199). Sant Feliu de Guíxols: Amics del Museu Municipal de Sant Feliu de Guíxols-Institut d'Estudis del Baix Empordà.

Garrido, Alfons; Pérez, Montse; Alegret, Joan Lluís; Darnaculleta, Montserrat (2010). Les Ordinacions de la pesquera de Calonge (s. XV-XVII). Palamós: Fundació Promediterrània per a la conservació, l'estudi i la difusió del patrimoni marítim.

GARRIDO, Alfons (2011). «La pesca al Cap de Creus a l'època moderna: Organització, gestió i conflictes per l'accés als recursos pesquers (segles XVI-XVIII)» (tesi doctoral). Girona: Universitat de Girona.

Genera, Margarida; Vellvehí, Jaume; Adell, Joan-Albert; Llovet, Eva Maria. «Sant Pol de Mar» [en línia]. Dins Catalunya Romànica. Fundació Enciclopèdia (disponible a: <www. encicplopedia.cat $>$ ) (darrera consulta: 01/02/2021).

Graupera, Joaquim (2016). «El monestir de Sant Pol, un edifici enigmàtic», El Sot de l'Aubó, núm. 58, p. 13-23.

Mallorquí, Elvis (2008). «El Castell de Sant Esteve de Mar i el litoral palamosí al segle XI», Estudis del Baix Empordà, núm. 27, p. 25-66.

Mallorquí, Elvis (2011). El llibre verd del bisbe de Girona (1362-1371): el delme i l'estructura feudal de la Diòcesi de Girona al segle XIV. Girona: Diputació de Girona.

Mallorquí, Elvis (2014). Pagesos $i$ homes de mar de Lloret: Estudi i edició del capbreu de la Pabordia de Novembre de 1317-1320. Lloret de Mar: Ajuntament de Lloret de Mar.

Mallorquí, Elvis (2015). Collecció diplomàtica dels Cartellà, cavallers de Maçanet de la Selva (1106-1301). Barcelona: Fundació Noguera.

Mallorquí, Elvis (2020). «La recaptació i el repartiment del delme a la Catalunya vella. El cas del Bisbat de Girona, segles XIII-XIV». Dins Catalán, Elena; Jover, Gabriel; Llopis, Enrique. El delme com a font per a la història rural. Girona: Associació d'Història Rural, Centre de Recerca d'Història Rural (Institut de Recerca Històrica) de la Universitat de Girona, Documenta Universitaria, p. 117-165.

MarCó, Xavier (2011). La senyoria feudal en un vessant de les Gavarres. Els dominis territorials de la Vall d'Aro al segle XV [en línia]. XIX Premi Joan Xirgo (disponible: $<$ www.gavarres.cat $>$ ) (darrera consulta: 02/02/2021).

MarTínez, Alejandro (2009). «Els senyors de la Marina de la Selva (ss. XIII-XIV)», Singladures, núm. 26, desembre, p. 23-41.

MarTínez, Alejandro (2010). L'expansió medieval de Blanes sota el domini dels vescomtes de Cabrera (segles XIII-XV). Blanes: Ajuntament de Blanes (Opuscles de l'Arxiu, 1). 
MarTínez, Alejandro (2012). El poder feudal, els seus agents i el territori. El vescomtat de Cabrera (1199-1423). Santa Coloma de Farners: Centre d'Estudis Selvatans (Estudis i Textos, 15).

MarTínez, Alejandro (2015). «Parentela aristocràtica, domini i projecció sociopolítica. Els vescomtes de Cabrera entre 1199 i 1423» (tesi doctoral). Girona: Universitat de Girona.

Mieres, Tomàs (2001). Costums de Girona. Cobos, Antoni (ed.). Girona: Centre de Recerca d'Història Rural (Biblioteca d'Història Rural. Documents, 3).

Montanari, Massimo (1999). «Economia di pesca e consumo di pesce nell'alto Medioevo». Dins Donati, Angela; Pasini, Paolo. La pesca. Realtà e simbolo. Fra tardo antico e medioevo. Milà: Leonardo Arte, p. 47-65.

OrTí, Pere (2000). Renda i fiscalitat en una ciutat medieval: Barcelona, segles XII-XIV. Barcelona: Consejo Superior de Investigaciones Científicas, Institución Milá y Fontanals.

Pladevall, Antoni (1972). El comtat d'Osona a mig segle XIV: Origen i extensió del Comtat d'Osona creat pel rei Pere III a favor de Bernat de Cabrera el 1 de març de 1356. Barcelona: Els Comtes de la Vall de Marlès.

Pons Espó, Margot (2002). El Fons municipal en pergami de l'antiga Universitat de Lloret de Mar. Lloret de Mar: Ajuntament de Lloret de Mar (Es Frares, 6).

Pons Guri, Josep Maria (1931). «El monestir de Sant Pol, Maresma», Paraula Cristiana, núm. 77, maig, p. 413-433.

Pons Guri, Josep Maria (1982). «La sentència sobre el castell de Lloret», Annals de l'Institut d'Estudis Gironins, vol. 26, p. 87-108.

Pons Guri, Josep Maria (1989). Recull d'Estudis d'Història Jurídica Catalana. Barcelona: Fundació Noguera, vol. III.

Pons Guri, Josep Maria (2003). «El castell de Montpalau. Pervivència de la jurisdicció d'un castell abandonat», Acta bistorica et archaeologica mediaevalia, núm. 25, p. 519-539.

Pujol, Marcel (2014). Un mar de conflictes. La pesca a Roses durant l'antic règim, 15921835. Roses: Ajuntament de Roses.

Pujol, Marcel (2018) La marina catalana a la Baixa Edat Mitjana: Sant Feliu de Guíxols, un port excepcional en la construcció $i$ carenat de coques, naus i naus grosses. Barcelona: Diputació de Barcelona-Institut d'Estudis Catalans (Premi Rafael Patxot i Jubert, 2).

Recasens, Josep M. (1997). «Notícies sobre la pesca i els pescadors de Tarragona. Segles xvi i XVII», Quaderns d'Història Tarraconense, núm. 15, p. 69-118.

Riera, Antoni (2009). «La pesca en el mediterráneo noroccidental durante la edad media». Dins La pesca en la edad media. Santiago de Compostella, et. al.: Dirección Xeral de Turismo. Consellería de Innovación e Industria. Xunta de Galicia, et. al., p. 121-143. Sáñez, Antonio (1795). Diccionario histórico de los artes de pesca nacional, Madrid, tom V. Schmidt, Tilmann; SABANÉs, Roser (2016). Butllari de Catalunya: documents pontificis originals conservats als arxius de Catalunya (1198-1417). Barcelona: Fundació Noguera. Soldevila, Xavier (2017). «Masos, "pobles", "vilanoves" i riberes: la xarxa de poblament als termes de Palafolls i Montpalau al segle XV». Dins El s. XV, temps de canvis i incerteses. Actes del Simposi n Maritima. Vilassar de Dalt: Museu Arxiu de Vilassar de DaltMaresme Medieval. 
SolDEviLA, Xavier (2018). Entre el Capaspre i la Tordera. Orígens i primeres passes de Malgrat (segles X-XV). Malgrat de Mar: Ajuntament de Malgrat de Mar.

Subiñà, Enric (2015). «El Maresme medieval. Exemples concrets de comunitats pageses» (tesi doctoral). Barcelona: Universitat de Barcelona.

VenditTelu, Marco (1992). «Diritti ed impianti di pesca degli enti ecclesiastici romani tra x e xiII secolo». Mélanges de l'École française de Rome. Moyen-Age, vol. 104, n. 2, p. 387430.

Zucchitello, Mario (1998). Tossa: la formació d'una vila. El comte l'abat i els tossencs. Tossa de Mar: Centre d'Estudis Tossencs.

ZucchitelLo, Mario (2011). «El delme del peix i la tasca de les collites a Tossa». Annals de l'Institut d'Estudis Gironins, vol. 52, p. 339-351.

Zucchiteluo, Mario (2013). En Mar i en Terra. Una història de Tossa i la seva gent. Tossa de Mar: Centre d'Estudis Tossencs.

Zug Tucci, Hannelore (1983). «La caccia, da bene comune a privilegio». Dins Romano, Ruggiero; Tucci, Ugo Storia d'Italia, Annali 6: Economia naturale, economia monetària n. 6, Torí: Giulio Einaudi, p. 397-445. 